\title{
30. BASALTS AND DOLERITES OF LATE CRETACEOUS AGE FROM THE CENTRAL CARIBBEAN
}

\author{
Thomas W. Donnelly, Department of Geology, St. Univ. of N.Y., Binghamton, N.Y. \\ William Melson, Dept. of Vulcanology \& Petrology, Smithsonian Institution, Washington, D.C. \\ Robert Kay, Lamont-Doherty Geological Observatory, Palisades, N.Y. \\ and \\ John J. W. Rogers, Dept. of Geology, Rice University, Houston, Texas
}

\section{INTRODUCTION}

Drilling at each of the five sites in the central Caribbean terminated in basalt or dolerite ranging in age from Coniacian (Sites 146 and 153) to early Campanian (Site 152). The distribution of these occurrences suggests a large basaltic province, and a tentative correlation with Reflector $B^{\prime \prime}$ suggests that these rocks occur over almost the entire Venezuelan Basin, as well as much of the northern Colombian Basin. Further considerations of late Cret aceous igneous occurrences all around the Caribbean suggest that the event which produced these magmas lasted about 10 million years, with more acid differentiates lasting perhaps another 10 million years at most. Also, igneous events in various Antillean islands and in South and Central America which had been considered peculiar to these areas and the result of local tectonic-magmatic activity are now seen to be interrelated and probably relatively independent of local tectonic events. Finally, the occurrence of these rocks, including the rocks from around the Caribbean and their presumed acid differentiates, may complicate the currently widely accepted views on the dichotomy of island arc and central ocean magmatism.

\section{OCCURRENCE OF THE CENTRAL CARIBBEAN BASALTS AND DOLERITES}

Figure 1 shows a schematic representation of the occurrence of basalts and dolerites at the five sites. At Site 146, two dolerite sills were encountered beneath a short Santonian section of mixed lithologies, dominantly limestones with intercalated radiolarian turbidites (sands), basaltic ash beds, and beds rich in reduced organic matter. Barite and fish debris are relatively conspicuous in smear slides and thin sections, and gypsum was found one one sample. Conspicuously graded basaltic ash beds with scattered fresh plagioclase and augite crystals, palagonite grains largely altered to mica, and occasional fragments of fine-grained porphyritic basalt, are interbedded with green micaceous clays two core barrels above the dolerite itself. These ash beds may be the result of the actual eruptions on the sea floor of the same magma which intruded lime oozes twenty meters below.

The upper dolerite sill has a lower chilled margin against a short section of Coniacian marbles which are recrystallized by the heat of the intrusion. These marbles are dominantly calcite and very well crystallized montmorillonite, with minor plagioclase and diopside and sparse fish debris.
The lower dolerite sill was penetrated in three cores. Even with a fresh roller bit (the result of re-entry into the hole a short distance above the dolerite) only 16 meters of penetration into the lower sill was possible.

At Site 150 , basaltic ash was identified in a short core of Santonian limestones. Two cores lower, beneath Coniacian sediment, a dolerite was encountered. The age of the eruption, dated by the basaltic ash, is probably Santonian.

At Site 151, intense drilling disturbance made interpretation of the Cretaceous section above the basalt difficult. The disturbed Santonian beds possibly contained basaltic ash, but the determination is not positive.

At Site 152, basalt was found beneath a section of Campanian limestones which contained one basaltic ash bed. The basalt contained marble inclusions, one of which yielded well-preserved but highly recrystallized early Campanian foraminifera.

At Site 153, mixed lithologies, reminiscent of those at Site 146 and containing basaltic ash beds, were found in the three cores (Santonian and Coniacian) above the basalt. These beds were dominantly limestone, with conspicuous glauconite and pyrite, and dark beds rich in fish debris.

In addition to recognizable basaltic ash, the sediments above the basalts contained conspicuous barite and fish debris at Sites 146 and 153; gypsum at Sites 146 and 152 (though not immediately above the basalt); abundant greenish mica at each locality; authigenic K-feldspar at Sites $146,150,152$, and 153; and chert micronodules at Site 146 conspicuously at all sites except Site 150 (conspicuously at Site 146 as intrabasinal turbidite beds). No ferruginous deposits were found at any of the sites.

The presence of dolerites at two localities and the absence of pillows suggests that the basaltic magmas are at least partly intrusive. The occurrence of repeated basaltic ash beds above the flows or sills is especially interesting because it implies eruption of basaltic materials over a considerable time span.

The ages inferred for the basalts (which are based on ash beds) at Sites 146, 150,152, and 153; sediments overlying basalt at Site 151 (minimum age only); and included blocks of dateable marble in dolerite at Site 146 and in basalt at Site 152 reveal no geographic pattern alone or in relation to the pattern of linear magnetic anomalies found in the Venezuelan Basin (Donnelly, magnetic anomaly studies in the eastern Caribbean, this volume). Thus, no analogy to midocean ridge vulcanism is apparent. Rather, the age pattern suggests a nearly simultaneous series of eruptions over a considerable area of the eastern and central Caribbean Sea. 
146

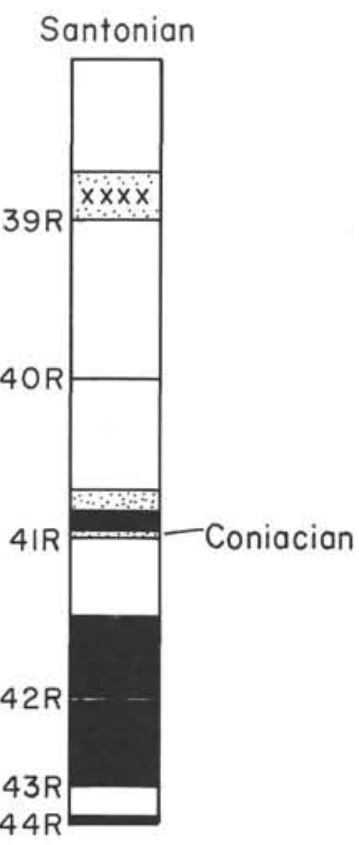

150

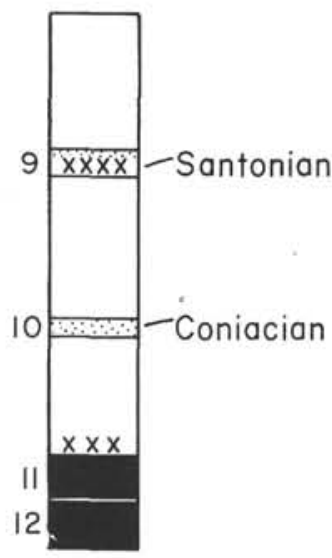

151

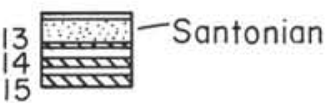

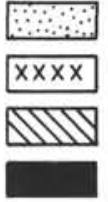

sediment

basaltic ash

basalt flow

dolerite intrusive

152

153

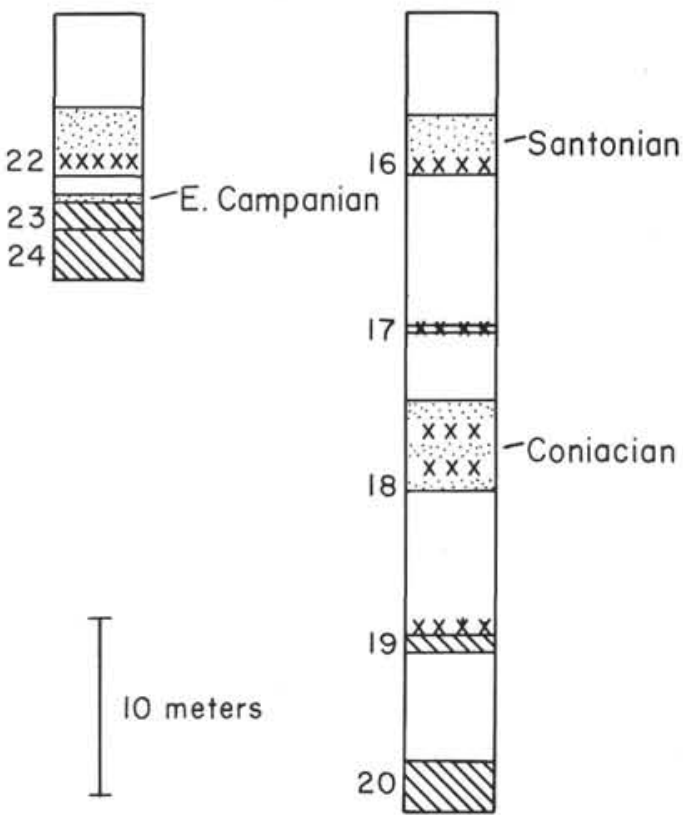

Figure 1. Diagramatic representation of cores for lower portions of Sites 146, 150,151, 152, and 153, showing lithologies and amount of recovered material.

\section{DESCRIPTION}

In hand specimen, the dolerites are fine- to mediumgrained, equigranular, dark gray, and apparently fresh. They are homogeneous, without inclusions, amygdules, or aggregates of crystals. They are sparsely veined with calcite. The basalts are more variable in appearance but show paler colors suggestive of slight alteration at Sites 151 and 152 . They are also more fractured and veined (with calcite and with greenish mica) and, at Sites 151 and 152, show conspicuous amygdules filled with very fine grained greenish mica. In no case can pillowing be recognized. The basalts of Site 152 contain conspicuous pink to white marble inclusions.

\section{MINERALOGY}

\section{Method}

A microprobe survey for $\mathrm{Fe}, \mathrm{Ca}, \mathrm{Ti}, \mathrm{Al}$, and $\mathrm{Mg}$ in pyroxenes, plagioclase, and secondary minerals was done on samples 146-41R-2(2-5), 146-43R-2(121-125), 151-13(CC), 152-23-1(107-121), and 153-20-2(80-84). The results of this survey are in Table 1 and some of the pyroxene data are plotted on a Fe-Mg-Ca diagram (Figures 3-6), a $\mathrm{TiO}_{2}$ versus $\mathrm{Al}_{2} \mathrm{O}_{3}$ diagram (Figure 7), and histogram of anorthite contents (Figure 2). For simplicity, the above samples are referred to as Samples 1, 2, 3,4, and 5, respectively, in the following discussion.

\section{Plagioclase}

The plagioclase phenocrysts and microlites are not of unusual compositions (Figure 2) except in Sample 2 where some of the large plagioclase phenocrysts have cores to
$\mathrm{An}_{86}$. Maximum An values are 72 in Sample 1, 73 in Sample 5 and 90, which is high for a basalt in Sample 3. This calcic plagioclase and the rare endiopside grains in the dolerite from Sample 2 indicate that (1) the original magma had a higher $\mathrm{Mg} / \mathrm{Fe}$ ratio and higher normative anorthite/ albite ratio than the other samples or (2) these crystals are xenocrysts, possibly parts of deep-seated cumulates. The latter is improbable on textural and chemical grounds.

The plagioclase phenocrysts and microlites (Figure 2) range in composition from calcic aridesine to calcic bytownite. Highly calcic grains were found in the Sample 2 dolerite and the Sample 3 basalt.

\section{Pyroxenes}

Early crystallizing pyroxenes are augite, close to $\mathrm{Fs}_{13} \mathrm{Wo}_{40} \mathrm{En}_{47}$, in Samples 1, 3, 4, and 5, while pyroxenes in ophitic intergrowth with plagioclase in Sample 2 are somewhat more magnesian, one falling just in the endiopside field.

In Sample 1, the coarsest grained sample, the pyroxenes show the most extreme fractionation; interstitial pyroxene and pyroxene margins range into the ferroaugite field with compositions to $\mathrm{Fs}_{46} \mathrm{Wo}_{39} \mathrm{En}_{15}$. Although somewhat scattered, the compositions are, with some exceptions, close to the Skaergaard trend for calcic pyroxenes and show the same low wollastonite for intermediate $\mathrm{Fe} / \mathrm{Mg}$ ratios.

The pyroxenes, with wollastonite contents up to only $\mathrm{Wo}_{41}$, are clearly not characteristic of alkali basalts, but are typical of tholeiites and olivine tholeiites.

Pyroxenes in Sample 1 also show a peculiar reversal in zoning which indicates that pyroxenes continued to crystallize after magnetite or other iron-rich phases began to crystallize. Some augite grains have normal cores rimmed 
TABLE 1A

Electron Microprobe Results

\begin{tabular}{|c|c|c|c|c|c|c|c|c|c|c|}
\hline Analysis & Description & $\mathrm{Fe}$ & $\mathrm{Ca}$ & $\mathrm{Mg}$ & An & Fs & Wo & En & $\begin{array}{l}\text { Calculated } \\
\text { Sum } \\
\text { (for px) }\end{array}$ & Sample ${ }^{b}$ \\
\hline 1 & Small granule & 5.0 & 14.5 & 11.2 & & 9.9 & 39.7 & 50.4 & 100.2 & 1 \\
\hline 2 & Px, large, clear grain & 5.1 & 14.6 & 10.6 & & 10.2 & 40.9 & 48.9 & 97.7 & 1 \\
\hline 3 & Px, large grain, center & 6.0 & 14.1 & 10.2 & & 12.2 & 40.0 & 47.8 & 97.3 & 1 \\
\hline 4 & Px, large grain, center & 6.5 & 13.8 & 10.0 & & 13.3 & 39.6 & 47.1 & 96.3 & 1 \\
\hline 5 & $\mathrm{Px}$, early & 6.9 & 13.4 & 10.6 & & 13.8 & 37.4 & 48.8 & 99.0 & 1 \\
\hline 6 & Px, early & 6.9 & 13.9 & 10.2 & & 13.9 & 38.9 & 47.3 & 98.9 & 1 \\
\hline 7 & $\mathrm{Px}$, late & 7.0 & 12.7 & 11.2 & & 13.9 & 35.0 & 51.2 & 99.7 & 1 \\
\hline 8 & Px, early & 7.1 & 14.6 & 9.7 & & 14.2 & 41.0 & 44.8 & 99.2 & 1 \\
\hline 9 & Px, early & 7.1 & 14.3 & 9.9 & & 14.4 & 40.0 & 45.6 & 98.9 & 1 \\
\hline 10 & Px, early & 7.5 & 14.2 & 9.8 & & 15.0 & 39.8 & 45.1 & 99.4 & 1 \\
\hline 11 & Px, unspecified sequence & 9.1 & 10.2 & 11.5 & & 18.3 & 28.6 & 53.1 & 98.6 & 1 \\
\hline 12 & Px, microlite & 9.5 & 10.6 & 11.2 & & 19.0 & 29.6 & 51.4 & 99.3 & 1 \\
\hline 13 & Px, late & 9.6 & 12.0 & 9.9 & & 19.6 & 34.0 & 46.5 & 98.5 & 1 \\
\hline 14 & Px, early & 10.0 & 11.8 & 10.0 & & 20.2 & 33.4 & 46.4 & 98.8 & 1 \\
\hline 15 & Px, margin (late) & 10.7 & 9.3 & 11.2 & & 21.6 & 26.1 & 52.2 & 98.9 & 1 \\
\hline 16 & Px, granule, center & 10.7 & 11.7 & 9.5 & & 22.0 & 33.4 & 44.6 & 98.4 & 1 \\
\hline 17 & Px, center & 10.9 & 13.0 & 8.6 & & 22.3 & 37.1 & 40.5 & 98.8 & 1 \\
\hline 18 & Px, center & 11.5 & 11.9 & 9.0 & & 23.6 & 34.0 & 42.4 & 98.8 & 1 \\
\hline 19 & $\mathrm{Px}$, late & 13.4 & 9.7 & 9.9 & & 27.0 & 27.2 & 45.8 & 100.5 & 1 \\
\hline 20 & Px, center, granule, late & 13.6 & 11.6 & 8.1 & & 28.1 & 33.4 & 38.5 & 99.1 & 1 \\
\hline 21 & $\mathrm{Px}$, late & 15.5 & 11.9 & 7.6 & & 31.4 & 33.5 & 35.1 & 102.5 & 1 \\
\hline 22 & Px, late & 15.9 & 12.7 & 6.6 & & 32.6 & 36.4 & 31.0 & 101.3 & 1 \\
\hline 23 & $\mathrm{Px}$, late & 15.8 & 11.4 & 6.4 & & 33.1 & 36.1 & 30.8 & 99.5 & 1 \\
\hline 24 & Px, late & 16.5 & 12.8 & 6.0 & & 34.2 & 37.1 & 28.7 & 101.0 & 1 \\
\hline 25 & Px, late & 17.2 & 11.6 & 6.4 & & 35.9 & 33.6 & 30.5 & 100.7 & 1 \\
\hline 26 & Px, late & 18.3 & 11.6 & 5.6 & & 38.6 & 34.1 & 27.4 & 100.1 & 1 \\
\hline 27 & Px, late & 21.8 & 13.1 & 3.3 & & 45.8 & 38.5 & 15.8 & 103.0 & 1 \\
\hline 1 & $\mathrm{Px}$, margin large $\mathrm{xl}$ & 5.6 & 14.6 & 10.8 & & 11.0 & 40.1 & 48.9 & 100.1 & 5 \\
\hline 2 & $\mathrm{Px}$, in plag-px aggregate; early & 5.6 & 14.7 & 10.4 & & 11.3 & 41.0 & 47.7 & 99.1 & 5 \\
\hline 3 & Px, early, center roundish phenocryst & 5.8 & 14.3 & 10.7 & & 11.6 & 39.6 & 48.8 & 101.0 & 5 \\
\hline 4 & Like 2 & 5.8 & 15.0 & 10.6 & & 11.4 & 41.0 & 47.6 & 98.5 & 5 \\
\hline 5 & Like 3 & 5.9 & 13.5 & 11.0 & & 11.9 & 37.6 & 50.5 & 98.5 & 5 \\
\hline 6 & Like 2 & 5.9 & 14.0 & 10.6 & & 11.8 & 39.2 & 49.0 & 98.4 & 5 \\
\hline 7 & Like 2 & 6.1 & 14.3 & 10.2 & & 12.3 & 40.3 & 47.4 & 98.2 & \\
\hline 8 & Like 2 & 6.1 & 13.8 & 10.2 & & 12.5 & 39.3 & 48.1 & 96.5 & 5 \\
\hline 9 & Like 2 & 6.2 & 13.4 & 11.0 & & 12.3 & 37.2 & 50.5 & 99.1 & 5 \\
\hline 10 & Like 2 , but margin & 7.1 & 14.1 & 10.0 & & 14.3 & 39.6 & 46.1 & 99.2 & 5 \\
\hline 11 & Px, late, granule & 8.5 & 12.8 & 10.2 & & 17.1 & 35.8 & 47.1 & 99.5 & 5 \\
\hline 13 & Px, late & 14.8 & 11.3 & 7.9 & & 30.3 & 32.5 & 32.7 & 100.5 & 5 \\
\hline 1 & $\mathrm{Px}$, in plag-px clot, early & 4.6 & 13.5 & 11.6 & & 9.1 & 37.7 & 53.2 & 97.8 & 2 \\
\hline 2 & Px, large phenocryst center & 5.6 & 14.0 & 10.6 & & 11.3 & 39.5 & 49.2 & 97.5 & 2 \\
\hline 3 & Like 2 & 5.6 & 14.5 & 10.4 & & 11.4 & 40.7 & 47.9 & 998.0 & 2 \\
\hline 4 & Like 2 & 5.9 & 13.6 & 11.0 & & 11.7 & 37.7 & 50.6 & 98.8 & 2 \\
\hline 5 & Px, intermediate & 8.4 & 14.2 & 9.2 & & 17.0 & 40.0 & 42.9 & & 2 \\
\hline 6 & $\mathrm{Px}$, in mesostasis & 14.1 & 11.8 & 7.7 & & 29.2 & 34.0 & 36.8 & 99.3 & 2 \\
\hline 1 & Pc, large center & & & & 72 & & & & & 1 \\
\hline 2 & Pc, enclosed in px & & & & 72 & & & & & \\
\hline 3 & Microlite & & & & 70 & & & & & 1 \\
\hline 4 & Pc, late & & & & 67 & & & & & 1 \\
\hline 5 & $\mathrm{Pc}$, in $\mathrm{px}$ & & & & 67 & & & & & 1 \\
\hline 6 & Pc, late & & & & 66 & & & & & 1 \\
\hline 7 & Pc, margin of 6 & & & & 61 & & & & & 1 \\
\hline 8 & Pc, late & & & & 59 & & & & & 1 \\
\hline 9 & Pc, late & & & & 46 & & & & & 1 \\
\hline 1 & $\mathrm{Pc}$, center, large $\mathrm{xl}$ & & & & 77 & & & & & 5 \\
\hline 2 & Pc, center, large xl & & & & 69 & & & & & 5 \\
\hline 3 & Pc, center, large xl & & & & 68 & & & & & 5 \\
\hline 4 & Pc, center, large xl & & & & 63 & & & & & 5 \\
\hline 5 & Pc, center, large xl & & & & 53 & & & & & 5 \\
\hline 6 & Pc, overgrowth on phenocryst & & & & 53 & & & & & 5 \\
\hline 7 & Pc, center of grain & & & & 51 & & & & & 5 \\
\hline 8 & Pc, microlite & & & & 48 & & & & & 5 \\
\hline 1 & Pc, large pheno, margin & & & & 85 & & & & & 2 \\
\hline 2 & Pc, 1 , beam moved slightly & & & & 85 & & & & & 2 \\
\hline 3 & Pc, center, large phenocryst & & & & 82 & & & & & \\
\hline
\end{tabular}


TABLE 1A - Continued

\begin{tabular}{|c|c|c|c|c|c|c|c|c|c|c|}
\hline Analysis & Description & $\mathrm{Fe}$ & $\mathrm{Ca}$ & $\mathrm{Mg}$ & An & Fs & Wo & EN & $\begin{array}{l}\text { Calculated } \\
\text { Sum } \\
\text { (for px) }\end{array}$ & Sample ${ }^{b}$ \\
\hline 4 & Pc, late & & & & 62 & & & & & 2 \\
\hline 5 & Pc, late, microlite & & & & 56 & & & & & 2 \\
\hline 1 & $\mathrm{~S}$ & 17.3 & 1.9 & 4.9 & & & & & & 1 \\
\hline 2 & $\mathrm{~S}$ & 17.8 & 2.0 & 5.6 & & & & & & 1 \\
\hline 3 & $\mathrm{~S}$, colloform & 17.5 & 1.8 & 5.9 & & & & & 104 & 1 \\
\hline 1 & $\mathrm{~S}$ & 18.5 & 1.6 & 8.0 & & & & & & 5 \\
\hline 2 & $\mathrm{~S}$ & 19.1 & 1.6 & 7.7 & & & & & & 5 \\
\hline 3 & $\mathrm{~S}$ & 18.7 & 1.6 & 7.9 & & & & & & 5 \\
\hline 4 & $\mathrm{~S}$ & 18.9 & 1.6 & 7.8 & & & & & & 5 \\
\hline 5 & $\mathrm{~S}$ & 18.0 & 1.6 & 7.5 & & & & & & 5 \\
\hline 1 & $\mathrm{~S}$, various spots; average & 12.11 & 1.6 & 10.7 & & & & & & 2 \\
\hline 1 & $\mathrm{Px}$ & 10.4 & 12.9 & 10.3 & & 20 & 34 & 48 & 104 & 3 \\
\hline 1 & $\mathrm{Px}$ & 12.3 & 10.0 & 7.5 & & 28 & 32 & 40 & 89 & 3 \\
\hline 3 & $\mathrm{Px}$ & 8.2 & 13.3 & 10.6 & & 16 & 36 & 48 & 102 & 3 \\
\hline 4 & $\mathrm{Px}$ & 9.0 & 12.7 & 10.9 & & 17 & 34 & 48 & 103 & 3 \\
\hline 5 & $\mathrm{Px}$ & 7.2 & 14.1 & 10.5 & & 14 & 38 & 47 & 101 & 3 \\
\hline 6 & $\mathrm{Px}$ & 9.1 & 14.5 & 9.9 & & 17.5 & 37 & 44 & 105 & 3 \\
\hline 7 & $\mathrm{Px}$ & 9.2 & 14.1 & 10.0 & & 18 & 38 & 44 & 104 & 3 \\
\hline 8 & $\mathrm{Px}$ & 8.9 & 14.3 & 9.7 & & 18 & 39 & 44 & 102 & 3 \\
\hline 9 & $P x$ & 9.6 & 13.5 & 10.1 & & 19 & 36 & 45 & 103 & 3 \\
\hline 10 & $\mathrm{Px}$ & 9.3 & 13.5 & 10.1 & & 19 & 37 & 44 & 98 & 3 \\
\hline 11 & $\mathrm{Px}$ & 10.0 & 11.8 & 10.9 & & 19 & 32 & 49 & 103 & 3 \\
\hline 12 & Px & 8.7 & 14.7 & 9.9 & & 17 & 39 & 44 & 104 & 3 \\
\hline 13 & $\mathrm{Px}$ & 8.8 & 13.2 & 10.3 & & 17 & 36 & 47 & 101 & 3. \\
\hline 14 & Px & 8.4 & 14.7 & 10.0 & & 16 & 40 & 44 & 104 & 3 \\
\hline 15 & $\mathrm{Px}$ & 9.1 & 12.2 & 11.5 & & 17 & 32 & 50 & 104 & 3 \\
\hline 16 & $\mathrm{Px}$ & 8.7 & 13.2 & 10.6 & & 17 & 36 & 47 & 103 & 3 \\
\hline 17 & $\mathrm{Px}$ & 9.4 & 13.8 & 10.6 & & 18 & 36 & 46 & 106 & 3 \\
\hline 18 & $\mathrm{Px}$ & 9.0 & 14.1 & 10.4 & & 17 & 36 & 46 & 105 & 3 \\
\hline 19 & $\mathrm{Px}$ & 9.4 & 13.8 & 10.6 & & 18 & 36 & 46 & 106 & 3 \\
\hline 20 & $\mathrm{Px}$ & 9.0 & 14.1 & 10.4 & & 17 & 37 & 46 & 105 & 3 \\
\hline 21 & $\mathrm{Px}$ & 11.3 & 13.4 & 9.2 & & 22 & 37 & 41 & 104 & 3 \\
\hline 22 & Px & 9.9 & 12.0 & 10.1 & & 20 & 34 & 47 & 100 & 3 \\
\hline 23 & $\mathrm{Pc}$ & & & & 90 & & & & & 3 \\
\hline 24 & $\mathrm{Pc}$ & & & & 80 & & & & & 3 \\
\hline 25 & $\mathrm{Pc}$ & & & & 60 & & & & & 3 \\
\hline 26 & Pc & & & & 60 & & & & & 3 \\
\hline
\end{tabular}

aPx = pyroxene $\mathrm{Pc}=$ plagioclase $; \mathrm{S}=$ "saponite."

$\mathrm{b}_{1}=146-41 \mathrm{R}-2(2-5) ; 2=146-43 \mathrm{R}-2(121-125) ; 3=151-13(C \mathrm{C}) ; 4=152-23-1(107-121) ; 5=153-20-2(80-84)$.

by progressively more iron-rich pyroxene which, on the very margin, grades again into more magnesian pyroxene. These outermost pyroxene rims, however, are lower in wollastonite content than the earlier crystallizing magnesian augite and correspond to the points that fall near the field of subcalcic augite in Figure 3 . This peculiar phenomena is worthy of more detailed examination.

Pigeonite, sometimes found as groundmass granules in some nearly holocrystalline "oceanic tholeiites," was not found in these samples.

\section{Oxides}

Very little information can be gleaned from the few, quantitatively inadequate, analyses run. The data would seem to indicate, though, that titanomagnetite is the principal primary opaque phase.

\section{"Saponite"}

A secondary, orange to brownish orange mica-like mineral is abundant interstially in Samples 1, 2, and 5. This is very similar to Na-rich saponites which are common in deep-sea basalts (Melson and Banks, 1968; Banks, 1971), and appears to form mainly deuterically. However, those in Table 1 are much more Fe-rich, and $\mathrm{Mg}$-poor than those described in the above references which, for two analysed samples, give $\mathrm{Fe}=7.4$ and 8.5 , and $\mathrm{Mg}=12.7$ and 11.0 , respectively. In these two described saponites, ferric iron is much more abundant than ferrious iron, with $\mathrm{Fe}_{2} \mathrm{O}_{3} / \mathrm{FeO}$ ratios of 3.1 and 14.5 , respectively. It is probably safe to speculate that $\mathrm{Fe}_{2} \mathrm{O}_{3}$ is very abundant in these Leg 15 "saponites", and they are thus important sources of much of the ferric iron reported in the bulk analyses.

\section{Other Minerals}

Olivine, divine pseudomorphs, pigeonite, and orthopyroxene were looked for but not found in any samples. A very fine-grained, fibrous or lath-shaped mineral, evidently a mica, was noted in amygdule and some vein fillings in samples from Sites 151 and 152. This mineral varied from very pale brown to vivid green in thin section and showed 
TABLE 1B

Additional Electron Microprobe Results, Pyroxenes

\begin{tabular}{rlrrc}
\hline Analysis & \multicolumn{1}{c}{ Ti } & Al & \multicolumn{1}{c}{ Mg } & Sample \\
\hline 1 & 0.40 & 3.5 & 8.9 & 4 \\
2 & 0.21 & 9.3 & 7.5 & 4 \\
3 & 0.81 & 4.3 & 13.5 & 4 \\
4 & 0.85 & 3.0 & 9.8 & 4 \\
5 & 0.92 & 3.8 & 12.7 & 4 \\
6 & 0.80 & 3.7 & 13.5 & 4 \\
7 & 0.39 & 3.4 & 13.6 & 4 \\
8 & 0.37 & 3.2 & 14.9 & 4 \\
9 & 0.51 & 3.6 & 14.2 & 4 \\
10 & 0.52 & 3.6 & 14.6 & 4 \\
11 & 0.46 & 3.2 & 14.4 & 4 \\
12 & 0.28 & 2.4 & 14.8 & 4 \\
13 & 0.60 & 3.7 & 15.0 & 4 \\
1 & 2.0 & 5.0 & 16.9 & 3 \\
2 & 1.0 & 2.8 & 16.6 & 3 \\
3 & 1.2 & 3.2 & 16.7 & 3 \\
4 & 1.3 & 2.7 & 16.9 & 3 \\
5 & 1.0 & 2.8 & 16.7 & 3 \\
6 & 0.91 & 2.8 & 16.6 & 3 \\
7 & 1.2 & 2.3 & 16.6 & 3 \\
8 & 1.3 & 2.9 & 16.4 & 3 \\
9 & 1.2 & 2.4 & 10.5 & 3 \\
10 & 1.7 & 4.8 & 14.6 & 3 \\
1 & 1.2 & 2.9 & 17.4 & 3 \\
1 & 0.37 & 3.1 & 16.8 & 1 \\
2 & 0.58 & 2.7 & 17.4 & 1 \\
3 & 0.70 & 1.8 & 12.8 & 1 \\
4 & 0.45 & 2.8 & 17.3 & 1 \\
5 & 0.46 & 3.1 & 16.0 & 1 \\
6 & 0.64 & 4.2 & 17.0 & 1 \\
7 & 0.44 & 3.4 & 16.5 & 1 \\
8 & 0.59 & 2.8 & 16.7 & 1 \\
9 & 0.51 & 3.8 & 16.8 & 1 \\
10 & 0.44 & 3.3 & 18.0 & 1 \\
11 & 0.65 & 1.8 & 12.3 & 1 \\
12 & 0.62 & 2.0 & 13.7 & 1 \\
13 & 0.39 & 2.4 & 16.2 & 1 \\
14 & 0.74 & 2.6 & 13.5 & 1 \\
15 & 0.68 & 2.3 & 12.6 & 1 \\
16 & 0.77 & 2.7 & 13.8 & 1 \\
& & & & \\
& & \\
16 &
\end{tabular}

$a_{1}=146-41 R-2(2-5) ; 3=151-13(C C) ;$ $4=152-23-1(107-121)$

moderate birefringence. Secondary calcite is very rare in all of these rocks.

\section{Texture}

The doleritic samples (Plates 1 and 2) are fine- to medium-grained, equigranular, subophitic to ophitic intergrowths of plagioclase and augite with squarish crystals of oxides and interstitial clear (Site 146 upper sill) to nearly opaque (Site 146 lower sill) or birefringent, micaceous (?), and brownish (Site 150) "saponite". The "saponite" differences evidently represent slightly different alteration products of interstitial glass. This material commonly shows crude concentric color banding and contains scattered, very fine grained opaques.

In the upper sill of Site 146, the shallowest sample studied (146-41R-2, 50-54) in thin section is also the coarsest (Plate 1, Figures 6,7) and, apparently, the freshest. The chilled lower contact of the same sill (Plate 1, Figure 8) consists of augite phenocrysts in a groundmass of intergrown subradial plagioclase laths and plumose pyroxene with abundant interstitial "saponite".

The basalts of Sites 151,152 , and 153 are rather different texturally. The basalt of Site 151 (Plate 2, Figures 3-6) is amygdular and somewhat glomeroporphyritic. Amygdules are filled exclusively with a very fine grained micaceous substance. Larger amygdules (Plate 2, Figure 3) show two generations of fillings, both mica, the latter of which is a deep in color. Evidently the first filling of the amygdules was deuteric. Plagioclase crystals of Site 151 have squarish ends and seldom show a tendency towards skeletal development. The groundmass consists of plagioclase laths, pyroxene and oxide grains, and scattered specks of a micaceous substance. Glomeroporphyritic aggregates consist entirely of plagioclase with a granular texture, a slight tendency towards interlocking of grains, and oscillatory zoning. The aggregates show a fine, micaceous alteration around the margins. Rare veins have calcite and the green micaceous substance.

The basalt of Site 152 (Plate 3, Figures 4 and 5) is amygdular and contains glomeroporphyritic aggregates similar to those of Site 151. The plagioclase laths of this basalt have forked ends and exhibit wide-spread skeletal development. The groundmass has a texture which is virtually identical to that of the Site 151 basalt, i.e., plagioclase laths and interstitial pyroxene and oxide grains. The amygdules show concentric fillings of variably colored, but dominantly green, very fine grained micaceous mineral. Both the amygdules and groundmass show light alteration, with aggregates of fine-grained, colloform iron oxide hydrates. Glomeroporphyritic aggregates of Site 152 are similar to those of Site 151 and consist of granular zoned plagioclase crystals and some augite. One glomeroporphyritic aggregate from Site 152 (Plate 3, Figure 5) is especially interesting in showing an ophitic aggregate of augite and plagioclase. A further development of this texture would presumably lead to the generally more coarse grained texture of the lower sample from Site 153 (Plate 3, Figure 3) or the texture of the dolerites.

The upper basalt of Site 153 (Plate 3, Figures 1 and 2) is fine-grained with subradial plagioclase laths intergrown with plumose pyroxene and with interstitial oxide grains and interstitial glass or "saponite." There are a few larger augite phenocrysts. The lower sample (Plate 3, Figure 3) is distinctly coarser and grades from a subophitic doleritic texture to a more granular, coarse basaltic texture. Some of the pyroxene grains have a noticeably wavy extinction and appear to be physically deformed. Glomeroporphyritic aggregates of plagioclase and augite are present.

Samples of a basalt (CURDRY) and dolerite (CURDIA) were collected during the ship's stop for repairs at Curacao. The basalt (Plate 3, Figure 6), a pillow basalt in the field, is finer grained than the deep-sea basalts, contains fresh augite phenocrysts and plagioclase phenocrysts which are saussuritizèd, and has the vitric groundmass replaced by feathery prehnite (?). The dolerite is very similar to the upper sill at Site 146, differing principally in a slightly more weathered appearance.

The distinction between basalts and dolerites is not very clear. The dolerites are uniformly more coarse grained, 


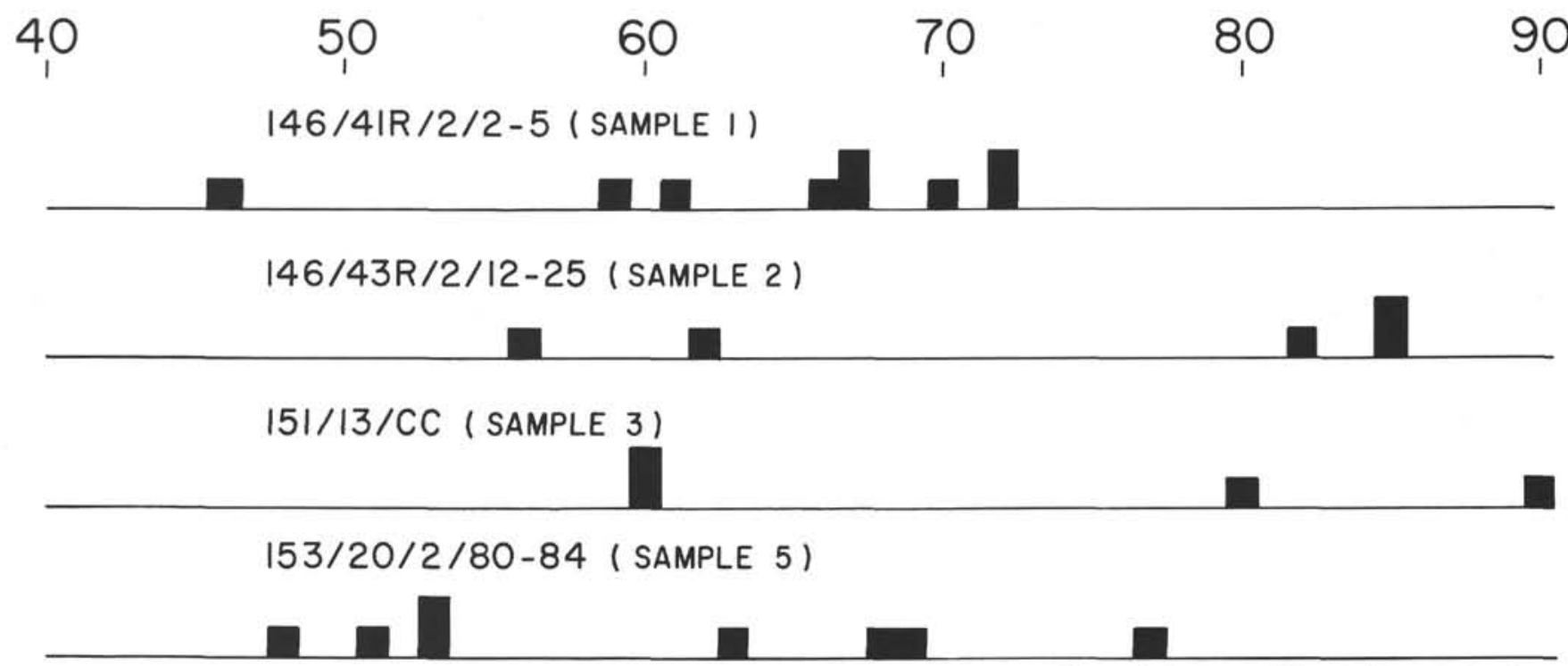

Figure 2. Histogram of anorthite contents (microprobe analyses) of plagioclases from dolerites of Site 146 and basalts of Sites 151 and 153.

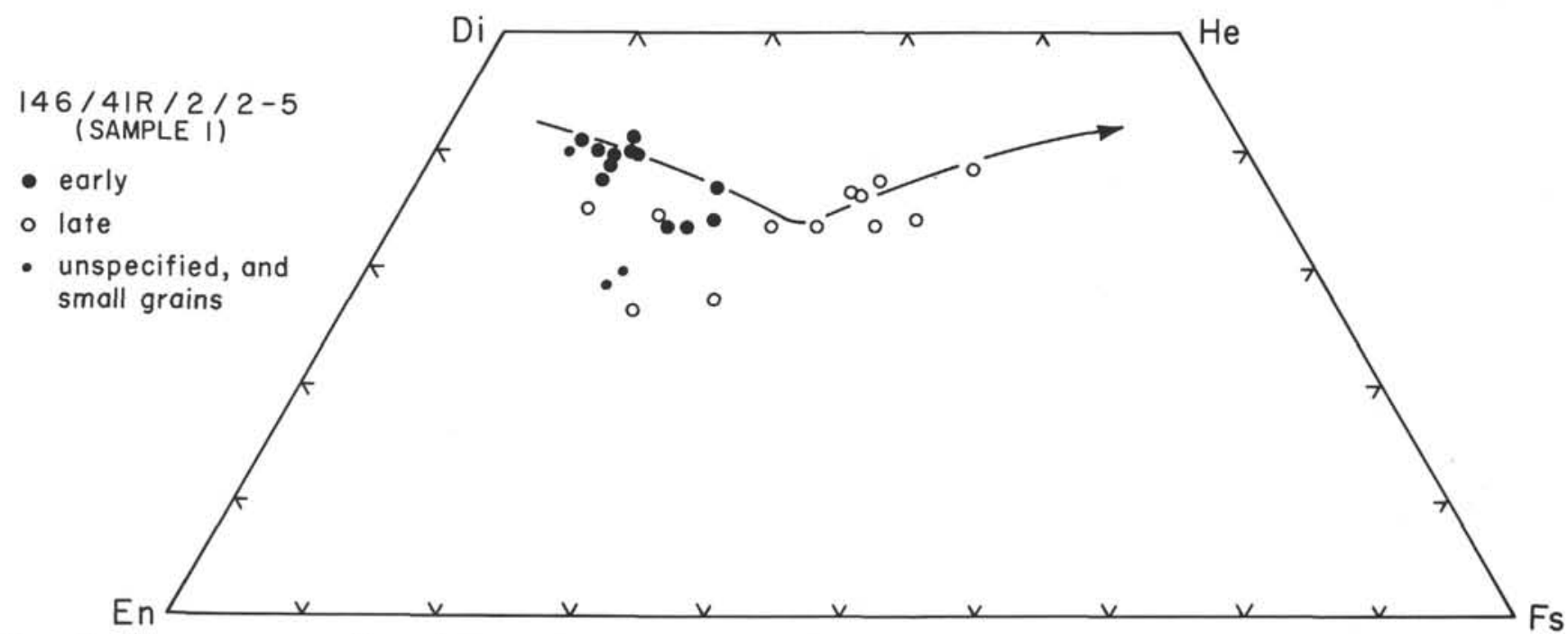

Figure 3. Pyroxene compositions (microprobe analyses, plotted on pyroxene quadrilateral showing Skaergaard trend) for upper dolerite sill at Site 146.

homogeneous, and lack amygdules and glomeroporphyritic aggregates. Basalts are finer grained, have more ragged and skeletal plagioclase, and commonly have both amygdules (Sites 151 and 152) and glomeroporphyritic aggregates (Sites 151, 152, and 153). However, the lower sample of Site 153 might by itself be called a dolerite, though it appears to underlie a fine-grained basalt. Failure to recover all of the core between the two samples presents the possibility that the lower sample could be a later intrusive, though the chemical compositions and mineralogy of the two samples are very similar.

\section{CHEMISTRY}

Table 2 shows major element, $\mathrm{U}$, and Th analyses for basalts and dolerites from Sites 146, 150, 151, 152, and
153 , as well as analyses of related basic igneous rocks from Curacao, Aves Ridge, Jamaica, Costa Rica, and the MidAtlantic Ridge. Rare-earth values for the Sites 146, 150, 151,152 and 153 basalts and dolerites, for the Curacao basalt, and for a Puerto Rican Bermeja complex amphibolite are shown in Table 3 and plotted in Figures 10 and 11 .

An inspection of the major element values for the basalts and dolerites from Sites 146, 150, and 153, as well as for the Curacao samples, shows remarkable similarities with typical oceanic tholeiites (compare analyses 1, 2, 17, and 18 with 24, Table 2). Analyses of samples from Sites 151 and 152, Jamaica, and Aves Ridge (analyses 13-16, 19-22) show higher potassium, higher titanium (Sites 151, 152 only), and slightly higher phosphorus. The Jamaican and Aves Ridge samples have notably higher aluminum and 


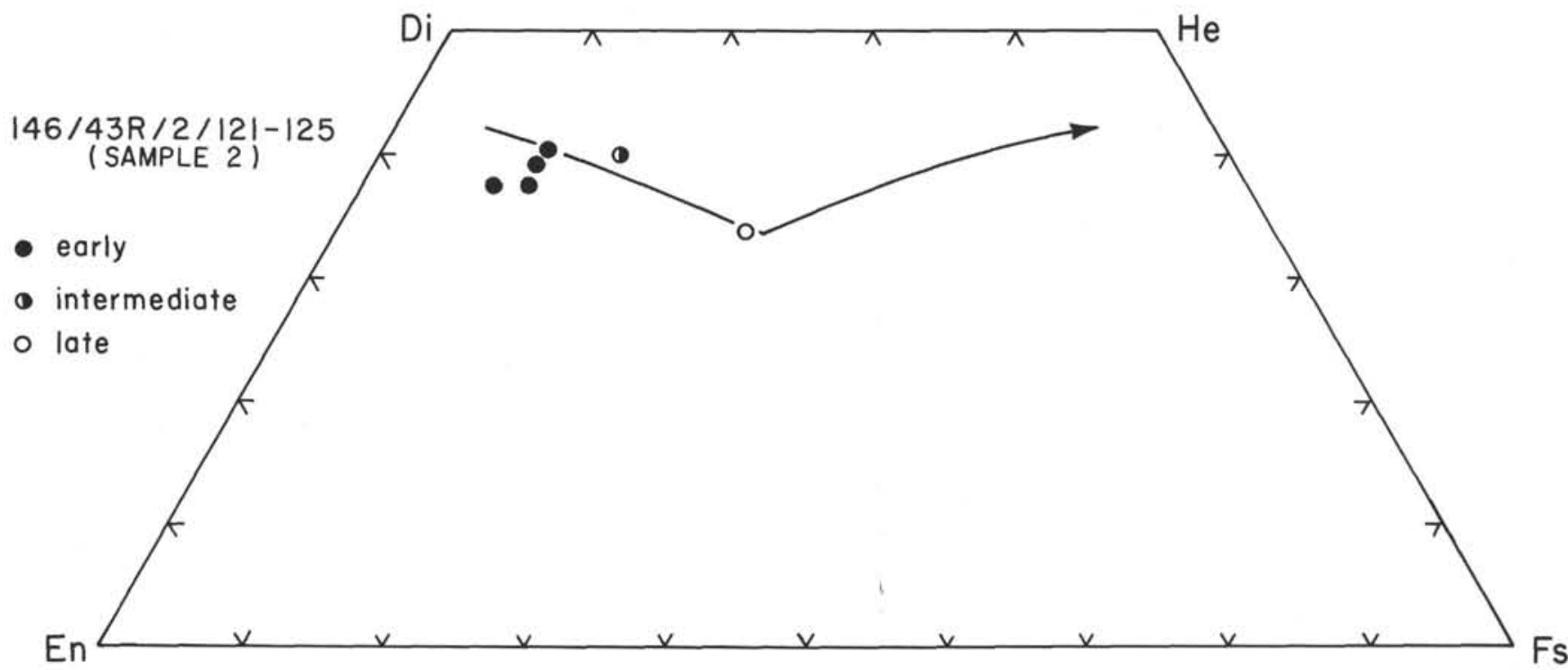

Figure 4. Pyroxene compositions (as in Figure 3) for lower dolerite sill at Site 146.

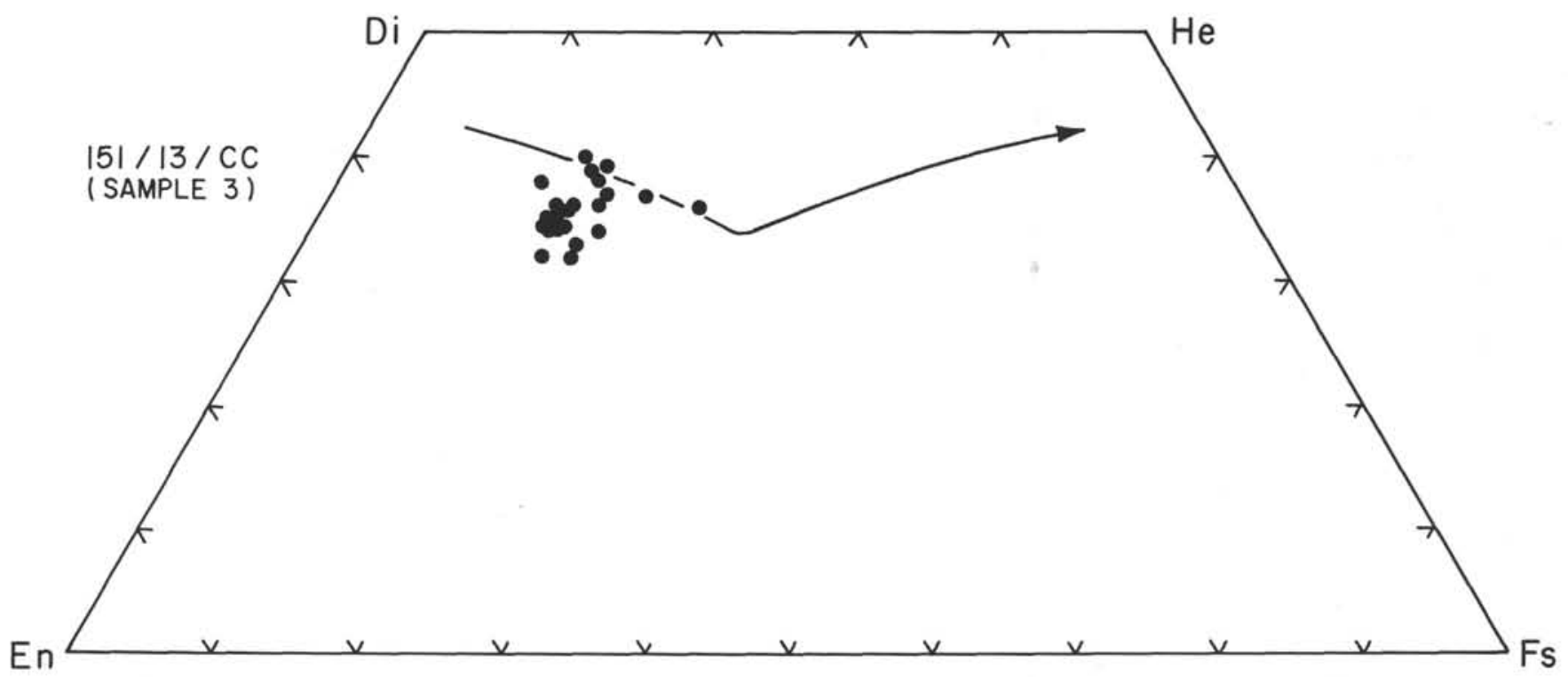

Figure 5. Pyroxene compositions (as in Figure 3) for basalt of Site 151.

somewhat lower magnesium; texturally, they are both crystal cumulates whose bulk chemistry may be expected to differ somewhat from that of the original magma.

\section{Effect of Weathering}

Figure 8 shows the distribution of $\mathrm{K}_{2} \mathrm{O}, \mathrm{H}_{2} \mathrm{O}+$, and the $\mathrm{Fe}_{2} \mathrm{O}_{3} / \mathrm{FeO}$ ratio with depth for the six igneous units of the five sites. An upward increase of $\mathrm{H}_{2} \mathrm{O}+$, and a corresponding increase in the $\mathrm{Fe}_{2} \mathrm{O}_{3} / \mathrm{FeO}$ ratio is evident in all the basalts and in the dolerite from Site 150. These values probably reflect submarine weathering. The dolerites from Site 146 do not clearly show this upward increase. Figure 9 shows $\mathrm{H}_{2} \mathrm{O}+$ plotted against the $\mathrm{Fe}_{2} \mathrm{O}_{3} / \mathrm{FeO}$ ratio with arrows pointing towards more shallow samples. Again, the correlation between these values may be seen. However, the trend, as shown in Figure 9, has more oxidized iron for corresponding water contents than typical Mid-Atlantic Ridge basalts. The possibility that these basalts and dolerites might be slightly more intrinsically oxidized that typical midocean ridge basalts should be considered.

Variations in $\mathrm{K}_{2} \mathrm{O}$ values, either as a function of depth or of water content, are less clear. Only Site 152 exhibits a clear correlation between these values. With the possible exception of Site 152, it would appear unlikely that potassium has been acquired from seawater through weathering. The high Th values for the high $\mathrm{K}_{2} \mathrm{O}$ basalts (Sites 151, 152) further indicate that the high potassium values probably reflect magmatic chemistry. 
T. W. DONNELLY, W. MELSON, R. KAY, J. J. W. ROGERS

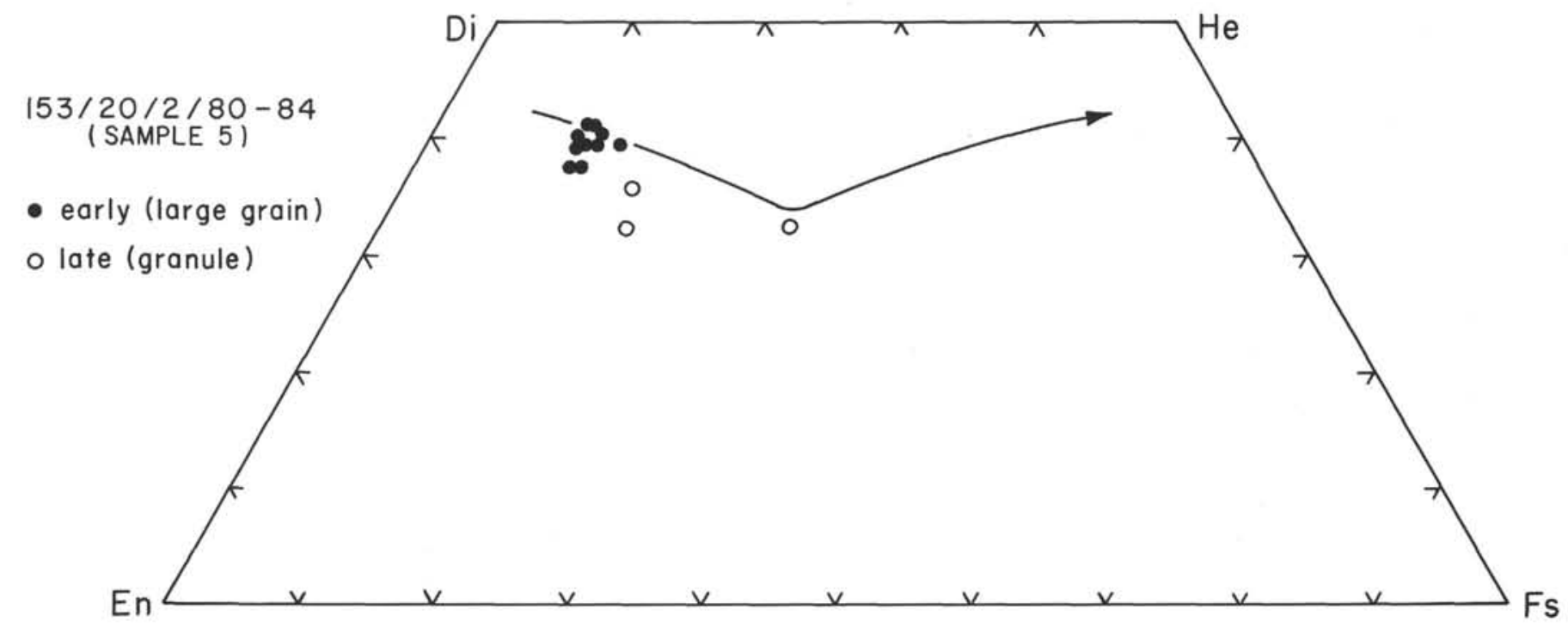

Figure 6. Pyroxene compositions (as in Figure 3) for basalt of Site 153.

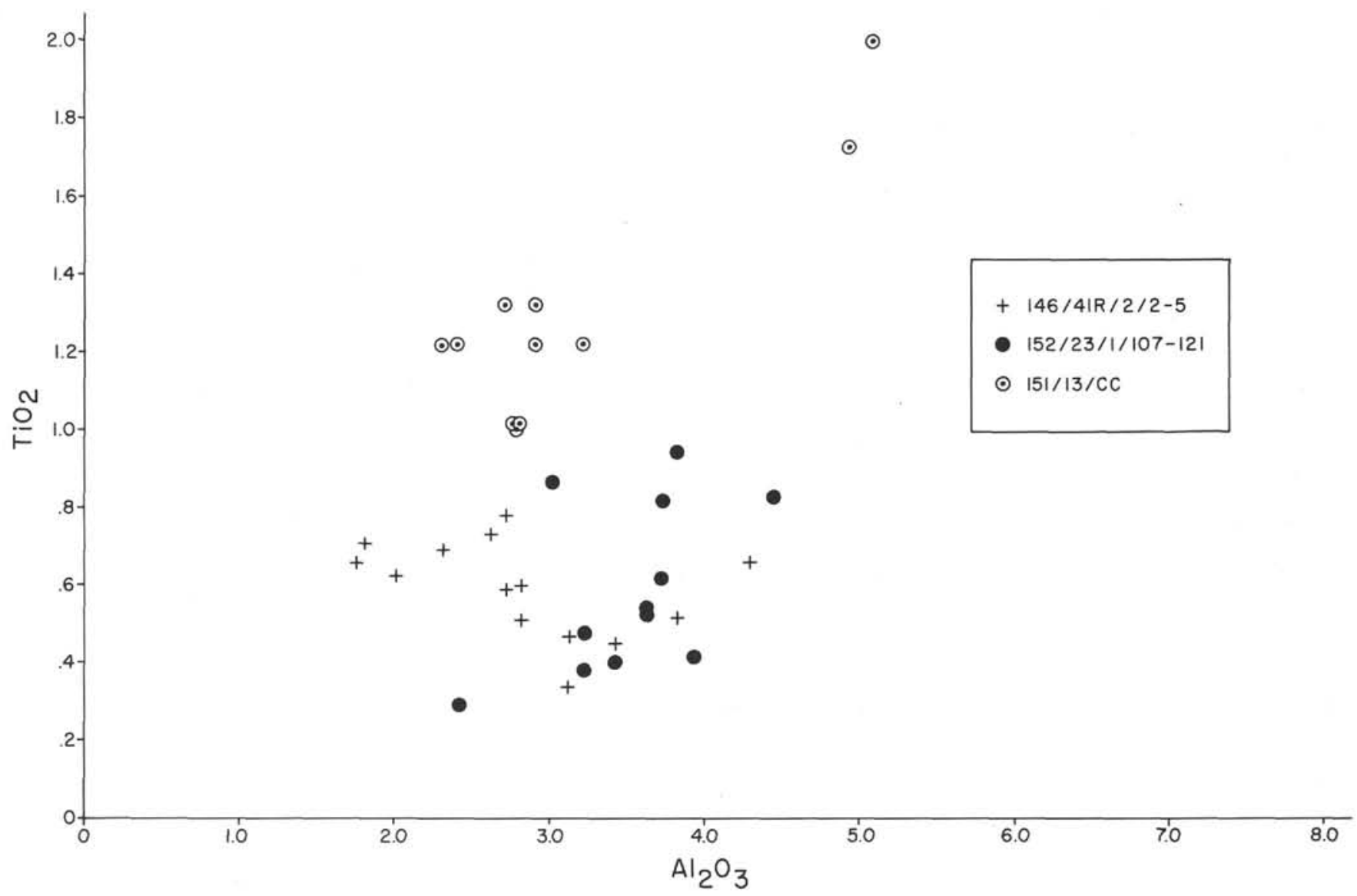

Figure 7. $\mathrm{TiO}_{2}$ vs $\mathrm{Al}_{2} \mathrm{O}_{3}$ for pyroxenes from three sites (microprobe analyses). 
TABLE 2

Major Element, Th and U Analyses ${ }^{\mathrm{a}}$

\begin{tabular}{|c|c|c|c|c|c|c|c|c|c|c|c|c|c|c|c|c|c|}
\hline Analysis & Sample & $\mathrm{SiO}_{2}$ & $\mathrm{TiO}_{2}$ & $\mathrm{Al}_{2} \mathrm{O}_{3}$ & $\mathrm{Fe}_{2} \mathrm{O}_{3}$ & $\mathrm{FeO}$ & $\mathrm{MnO}$ & $\mathrm{HgO}$ & $\mathrm{CaO}$ & $\mathrm{Na}_{2} \mathrm{O}$ & $\mathrm{K}_{2} \mathrm{O}$ & $\mathrm{P}_{2} \mathrm{O}_{5}$ & $\mathrm{H}_{2} \mathrm{O}+$ & $\mathrm{CO}_{2}$ & Sum & $\begin{array}{c}\text { Th } \\
\text { (ppm) }\end{array}$ & $\underset{(\mathrm{ppm})}{\mathrm{U}}$ \\
\hline 1 & $146-41 R-2(2-5)$ & 48.9 & 0.96 & 15.50 & 4.64 & 6.56 & 0.18 & 7.16 & 12.61 & 2.20 & 0.08 & 0.07 & 1.54 & 0.00 & 100.40 & & \\
\hline 2 & 146-41R-1(90-94) & 48.5 & 0.89 & 14.82 & 5.73 & 5.80 & 0.23 & 7.81 & 11.83 & 2.29 & 0.10 & 0.05 & 1.56 & 0.00 & 99.61 & & \\
\hline 3 & $146-42 \mathrm{R}-1(117-120)$ & 48.8 & 1.03 & 15.23 & 3.82 & 6.40 & 0.21 & 8.03 & 14.00 & 1.78 & 0.08 & 0.08 & 1.17 & 0.27 & 100.90 & & \\
\hline 4 & $146-42 R-3(40-44)$ & 48.6 & 1.12 & 15.40 & 3.89 & 6.60 & 0.21 & 7.90 & 13.61 & 1.65 & 0.08 & 0.08 & 0.94 & 0.20 & 100.28 & & \\
\hline 5 & $146-43 R-1(131-143)$ & 48.4 & 1.07 & 15.48 & 4.03 & 6.12 & 0.16 & 8.11 & 12.27 & 1.53 & 0.08 & 0.08 & 1.49 & 0.24 & 99.06 & 0.00 & 0.22 \\
\hline 6 & $146-43 R-2(121-125)$ & 49.3 & 1.16 & 15.15 & 4.31 & 6.36 & 0.17 & 8.05 & 12.47 & 1.76 & 0.10 & 0.09 & 1.37 & 0.20 & 100.49 & & \\
\hline 7 & $146-43 R-4(27-30)$ & 47.5 & 1.05 & 14.58 & 4.08 & 6.16 & 0.17 & 8.20 & 13.34 & 1.78 & 0.08 & 0.08 & 1.28 & 1.31 & 99.61 & & \\
\hline 8 & $150-11-2(63-67)$ & 49.2 & 1.36 & 16.66 & 5.51 & 4.60 & 0.06 & 7.88 & 8.98 & 2.79 & 0.20 & 0.11 & 1.44 & 0.52 & 99.31 & & \\
\hline 9 & $150-12-1(130-135)$ & 48.9 & 1.22 & 15.23 & 3.99 & 6.28 & 0.19 & 7.83 & 13.08 & 1.95 & 0.10 & 0.08 & 1.13 & 0.48 & 100.46 & & \\
\hline 10 & $150-12(\mathrm{CC})$ & 48.6 & 1.17 & 14.98 & 4.38 & 6.80 & 0.11 & 8.14 & 12.34 & 1.88 & 0.12 & 0.08 & 1.23 & 0.00 & 99.83 & 0.09 & 0.10 \\
\hline 11 & CURDIA $^{\mathrm{b}}$ & 50.1 & 1.02 & 16.33 & 3.00 & 7.36 & 0.14 & 8.06 & 11.38 & 2.36 & 0.17 & 0.06 & 1.99 & 0.00 & 101.97 & 0.33 & 0.11 \\
\hline 12 & CURDRYc & 49.8 & 1.02 & 15.30 & 2.28 & 7.76 & 0.13 & 8.16 & 11.16 & 2.84 & 0.19 & 0.07 & 1.79 & 0.00 & 101.10 & 0.93 & 0.14 \\
\hline 13 & $151-13(\mathrm{CC})$ & 48.1 & 2.53 & 13.96 & 9.60 & 4.68 & 0.14 & 5.81 & 7.69 & 2.37 & 1.62 & 0.26 & 2.51 & 0.64 & 99.91 & & \\
\hline 14 & $151-15-1(109-125)$ & 46.5 & 2.51 & 13.80 & 8.32 & 5.16 & 0.14 & 5.91 & 9.71 & 2.22 & 1.90 & 0.25 & 2.03 & 1.78 & 100.23 & 2.19 & 0.91 \\
\hline 15 & $152-23-1(107-121)$ & 48.8 & 1.57 & 14.86 & 9.73 & 4.36 & 0.08 & 6.76 & 8.22 & 2.55 & 1.03 & 0.16 & 2.54 & 0.27 & 100.93 & & \\
\hline 16 & $152-24-2(55-67)$ & 47.8 & 1.59 & 14.90 & 7.46 & 4.60 & 0.15 & 6.98 & 9.30 & 2.78 & 0.70 & 0.14 & 1.69 & 1.16 & 99.25 & 1.66 & 0.30 \\
\hline 17 & $153-19-1(116-120)$ & 47.8 & 1.68 & 17.21 & 6.55 & 5.20 & 0.23 & 7.10 & 9.38 & 2.82 & 0.10 & 0.13 & 2.12 & 0.17 & 100.49 & & \\
\hline 18 & $153-20-2(71-79)$ & 48.6 & 1.48 & 14.69 & 5.09 & 7.32 & 0.17 & 7.00 & 11.89 & 2.27 & 0.04 & 0.11 & 0.81 & 0.17 & 99.64 & 0.61 & 0.15 \\
\hline 19 & JAMDIA $^{\mathrm{d}}$ & 49.6 & 1.15 & 18.50 & 5.37 & 4.68 & 0.14 & 4.39 & 8.98 & 2.97 & 0.97 & 0.19 & 1.91 & 0.00 & 98.85 & 1.19 & 0.75 \\
\hline 20 & WISC $26^{\mathrm{d}}$ & 50.6 & 1.21 & 17.45 & $11.53^{\mathrm{h}}$ & & 0.22 & 5.19 & 9.71 & 3.04 & 0.86 & 0.19 & n.d. . & n.d. & 100.00 & & \\
\hline 21 & $1317-3^{\mathrm{e}}$ & 44.23 & 0.50 & 22.86 & 4.68 & 3.82 & 0.13 & 5.77 & 10.66 & 2.98 & 0.78 & 0.09 & 3.03 & 0.31 & 99.84 & & \\
\hline 22 & $1318-1 \mathrm{D}^{\mathrm{e}}$ & 44.0 & 0.65 & 20.90 & 4.29 & 4.32 & 0.12 & 5.40 & 11.43 & 1.66 & 0.61 & 0.13 & n.d. & n.d. & & & \\
\hline 23 & Costa Rica ${ }^{f}$ & 48.4 & 1.18 & 14.4 & 4.3 & 7.7 & 0.19 & 7.9 & 11.1 & 2.10 & 0.43 & 0.20 & 2.0 & 0.10 & & & \\
\hline
\end{tabular}

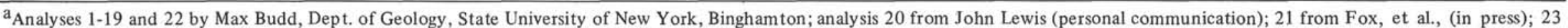
from Henningson and Weyl (1967) and Dengo (1972); and analysis 24 from Melson, Thompson, and Van Andel (1968).

${ }^{b_{S}}$ Samples from main road between Williamstad and Julianadorp, Curacao.

'Sample from Curacao Drydock, Curacao.

${ }^{d}$ Samples from a deep well, Santa Cruz Mountains, Jamaica.

esamples dredged from southernmost Aves Ridge.

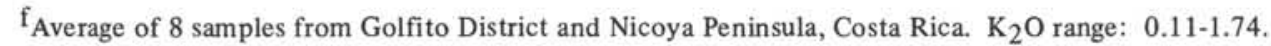

$\mathrm{g}_{\text {Average of }} 33$ analyses from Mid-Atlantic Ridge (Melson, Thompson, and VanAndel, 1968).

$\mathrm{h}_{\text {Total iron as }} \mathrm{Fe}_{2} \mathrm{O}_{3}$. 
TABLE 3

Rare Earth and Barium Abundances, Leg 15 Basalts and Dolerites ${ }^{\mathrm{a}}$

\begin{tabular}{|c|c|c|c|c|c|c|c|c|c|c|c|}
\hline Sample & $\mathrm{Ba}$ & $\mathrm{La}$ & $\mathrm{Ce}$ & $\mathrm{Nd}$ & $\mathrm{Sm}$ & $\mathrm{Eu}$ & Gd & Dy & Er & $\mathrm{Yb}$ & $\mathrm{Lu}$ \\
\hline $146-43 \mathrm{R}-1(131-143)$ & 13.0 & 2.30 & 7.60 & 6.36 & 2.16 & 0.84 & 3.00 & 3.60 & 2.20 & 2.10 & 0.284 \\
\hline $150-12$ (CC) & 13.5 & 2.63 & 8.09 & 6.75 & 2.31 & 0.89 & 3.20 & 3.85 & 2.36 & 2.32 & \\
\hline $151-15-1(109-125)$ & 40.2 & 14.6 & 35.4 & 22.4 & 5.65 & 1.89 & 6.10 & 5.55 & 2.79 & 2.32 & 0.295 \\
\hline $152-24-2(55-67)$ & 6.9 & 1.75 & 7.31 & 8.16 & 3.35 & 1.25 & 5.18 & 6.58 & 4.12 & 3.96 & 0.52 \\
\hline $153-20-2(71-79)$ & 12.5 & 3.36 & 9.86 & 8.45 & 2.94 & 1.11 & 4.23 & 5.10 & 3.20 & 3.15 & 0.422 \\
\hline CURDRY & 16.1 & 3.06 & 8.24 & 6.31 & 2.03 & 0.77 & & 3.22 & 1.97 & 1.92 & \\
\hline TD63-64 & 51.9 & 3.65 & 13.3 & 12.6 & 4.40 & 1.48 & 6.28 & 7.75 & 4.90 & 4.74 & 0.62 \\
\hline
\end{tabular}

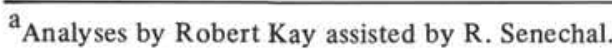

$\mathrm{b}_{\text {Sample from Curacao basalt. }}$

${ }^{\mathrm{c}}$ Puerto Rican amphibolite.

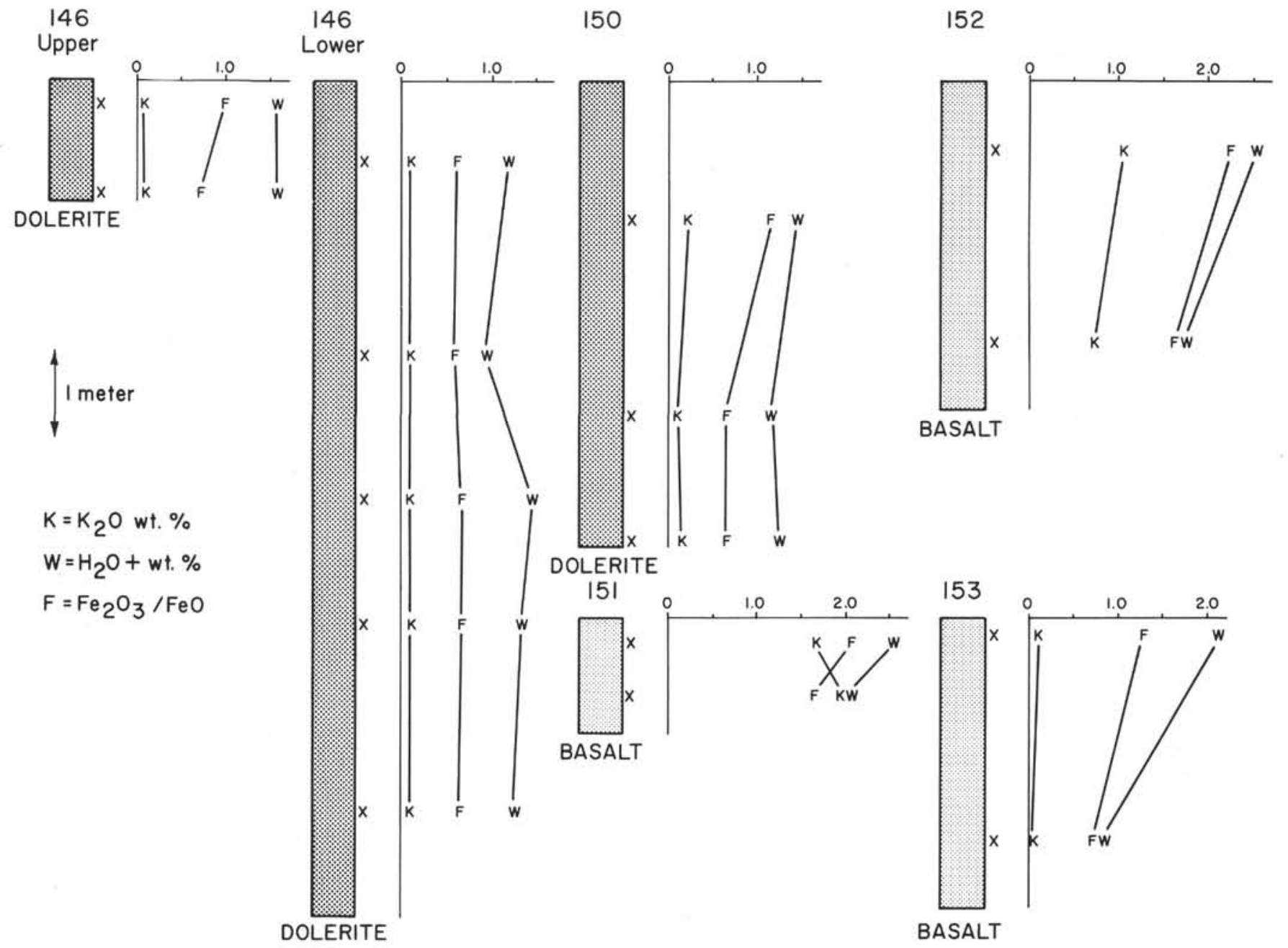

Figure 8. Distribution of $\mathrm{K}_{2} \mathrm{O}, \mathrm{H}_{2} \mathrm{O}$, and $\mathrm{Fe}_{2} \mathrm{O}_{3} / \mathrm{FeO}$ ratio for dolerites and basalts, plotted against depth. 


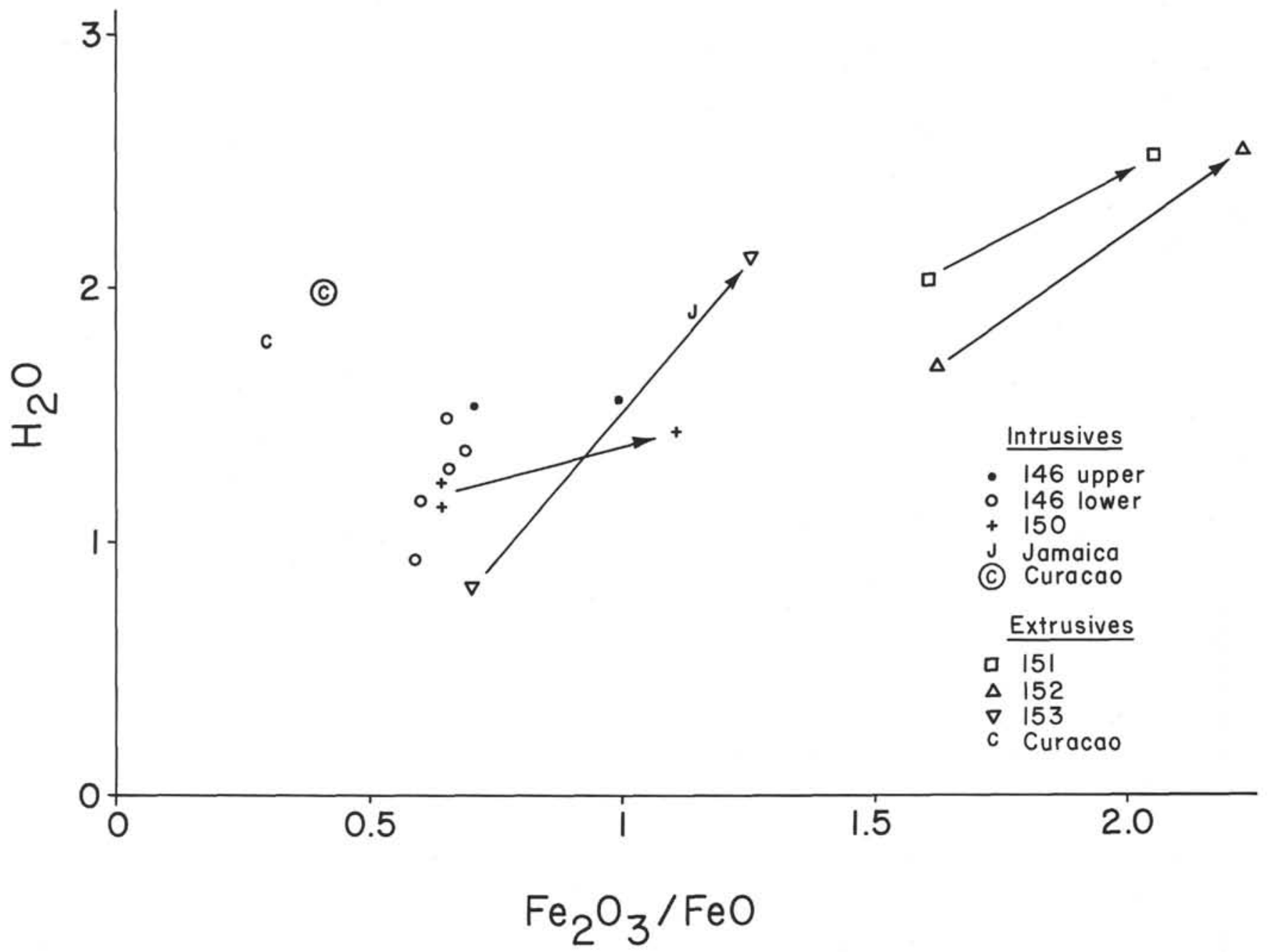

Figure 9. Plot of $\mathrm{H}_{2} \mathrm{O}$ vs. $\mathrm{Fe}_{2} \mathrm{O}_{3} / \mathrm{FeO}$ ratio for basalts and dolerites, including Jamaica and Curacao samples.

\section{Potassium}

Although $\mathrm{K}_{2} \mathrm{O}$ is commonly low in oceanic basalts (Melson, Thompson, and Von Andel's 1968 average of 33 Mid-Atlantic Ridge basalts is 0.26 per cent $\mathrm{K}_{2} \mathrm{O}$ ), alkalic basalts have considerably higher values. Engel and Engel (1963) report a value of 1.00 per cent $\mathrm{K}_{2} \mathrm{O}$ from an apparently fresh basalt from the northeastern Pacific Ocean. Engel and Engel (1964) give the average value of $\mathrm{K}_{2} \mathrm{O}$ as 1.54 for alkalic basalts of the Mid-Atlantic Ridge. In a broad survey of oceanic ridge basalts, Kay, Hubbard, and Gast (1970) found only two samples out of thirty-three with $\mathrm{K}_{2} \mathrm{O}$ greater than 0.5 per cent. One of these ( $7 \mathrm{~F}$ with 0.6 per cent $\mathrm{K}_{2} \mathrm{O}$ ) has an enrichment of light rare-earths (Figure 11); the other is a fresh glass with a "flat" rare-earth pattern, but generally high values. The average of twentyeight Icelandic tholeiites is 0.56 per cent $\mathrm{K}_{2} \mathrm{O}$ (Heier et al., 1966). The average of twenty-four lavas from Kilauea, Hawaii is 0.45 per cent $\mathrm{K}_{2} \mathrm{O}$ (Macdonald, 1949), and seven Hawaiian alkali olivine basalts average 0.67 per cent $\mathrm{K}_{2} \mathrm{O}$ (Kuno, et al., 1957).

The occurrence within the oceans of basalts with greater than 1 per cent $\mathrm{K}_{2} \mathrm{O}$ would seem to be limited to (a) some distinctly alkalic basalts, (b) basalts which have acquired potassium from submarine weathering, or (c) exceptional cases. Although many aspects of the mineralogy of the Site 152 basalt show the effects of weathering, the more potassic Site 151 basalt appears fresher. Both rocks have high values of Th. The pyroxenes of Site 152 are moderately enriched in $\mathrm{Ti}$ and $\mathrm{A} 1$ (Figure 7), and the rock could be called mildly alkalic. We conclude that the high potassium content of these two sites is probably intrinsic and reflects either the magma source or effect of passage through continental crustal material enriched in potassium. In this regard, it is interesting to note that the Jamaican dolerite and the Aves Ridge dolerites also have higher potassium.

\section{Thorium}

The Th values from these samples fall into three groups: low (Sites 146, 150, CURDIA), high (Sites 151, 152, CURDRY, JAMDIA), and intermediate (Site 153). The low values are typical for oceanic tholeiites (Tatsumoto, Hedge, and Engel, et al., 1965, give an average Th of $0.18 \mathrm{ppm}$; Morgan and Lovering, 1965, report Th of 0.23 from the 


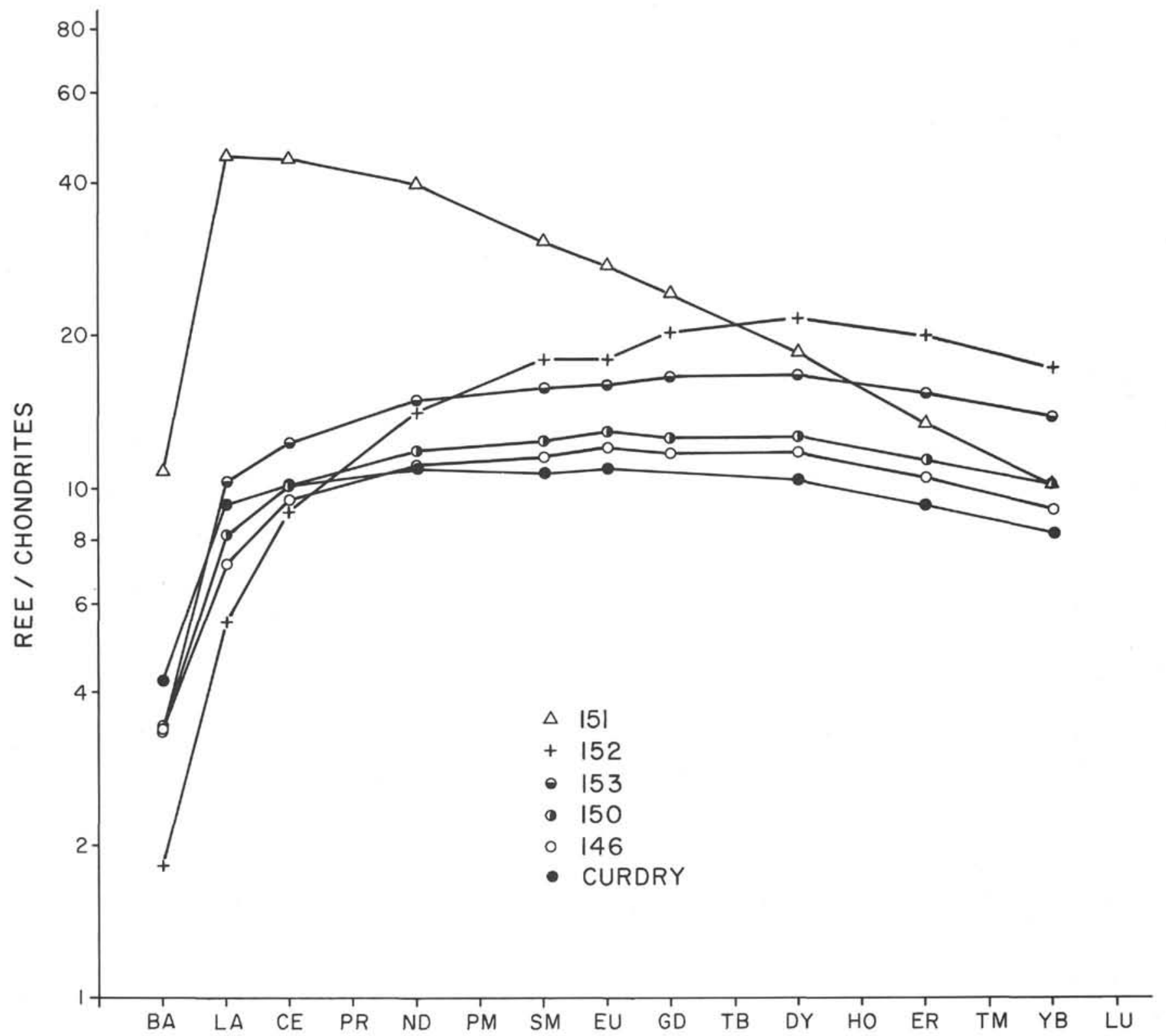

Figure 10. Rare-earth distributions for basalts and dolerites of central Caribbean, including Curacao basalt sample, plotted as multiples of chondritic concentrations. Ionic radii decrease from $\mathrm{Ba}$ to $\mathrm{Yb}$.

MOHOLE basalt). The higher values are more troublesome. In summarizing Hawaiian basalt values, Tatsumoto (1966) and Heier and Rogers (1963) showed that Th is about 0.4 to $0.6 \mathrm{ppm}$ in tholeiites but rises to about $1.5 \mathrm{ppm}$ in alkalic basalts. Watkins, Holmes, and Hagerty (1967) find variable Th averaging $1.06 \mathrm{ppm}$ in an Icelandic lava flow and Heier et al. (1966) find an average of $1.1 \mathrm{ppm}$ for three Icelandic tholeiites. Continental tholeiites, however, average much higher in Th: $3.2 \mathrm{ppm}$ (Antarctic); $1.8 \mathrm{ppm}$ (Karroo); $2.1 \mathrm{ppm}$ (Tasmania) (Compston, McDougall, and Heier, 1968); $1.8 \mathrm{ppm}$ (Palisades Sill); $1.02 \mathrm{ppm}$ (Columbia River)(Heier and Rogers, 1963); 2.9 ppm (Dillsburg, Pennsylvania); 3.2 ppm (Great Lake, Tasmania)(Gottfried, Greenland, and Campbell, 1968). Thus, the higher values from the more westerly samples of Leg 15 and from Jamaica would appear to be closer to continental Th values.

\section{Rare Earths}

The rare earth (RE) and Ba content of six Leg 15 basalts is given in Table 3 and plotted in Figure 10. The samples are very similar to olivine tholeiites dredged from axial regions of actively spreading mid-oceanic ridges. The light-RE and Ba-depleted types (Sites 146, 150, 152 and 153) contrast with the light-RE enriched sample (Site 151) and the sample having nearly chondritic RE distribution (CURDRY). All three types have been found among midocean ridge basalts (see Figure 11), although the light$\mathrm{RE}$ depleted type is most common.

Common features of the light-RE depleted Leg 15 basalts and midocean ridge basalts include the following:

1) Similar distribution patterns of the rare earths Gd-Lu with total concentrations varying by a factor of two. For 


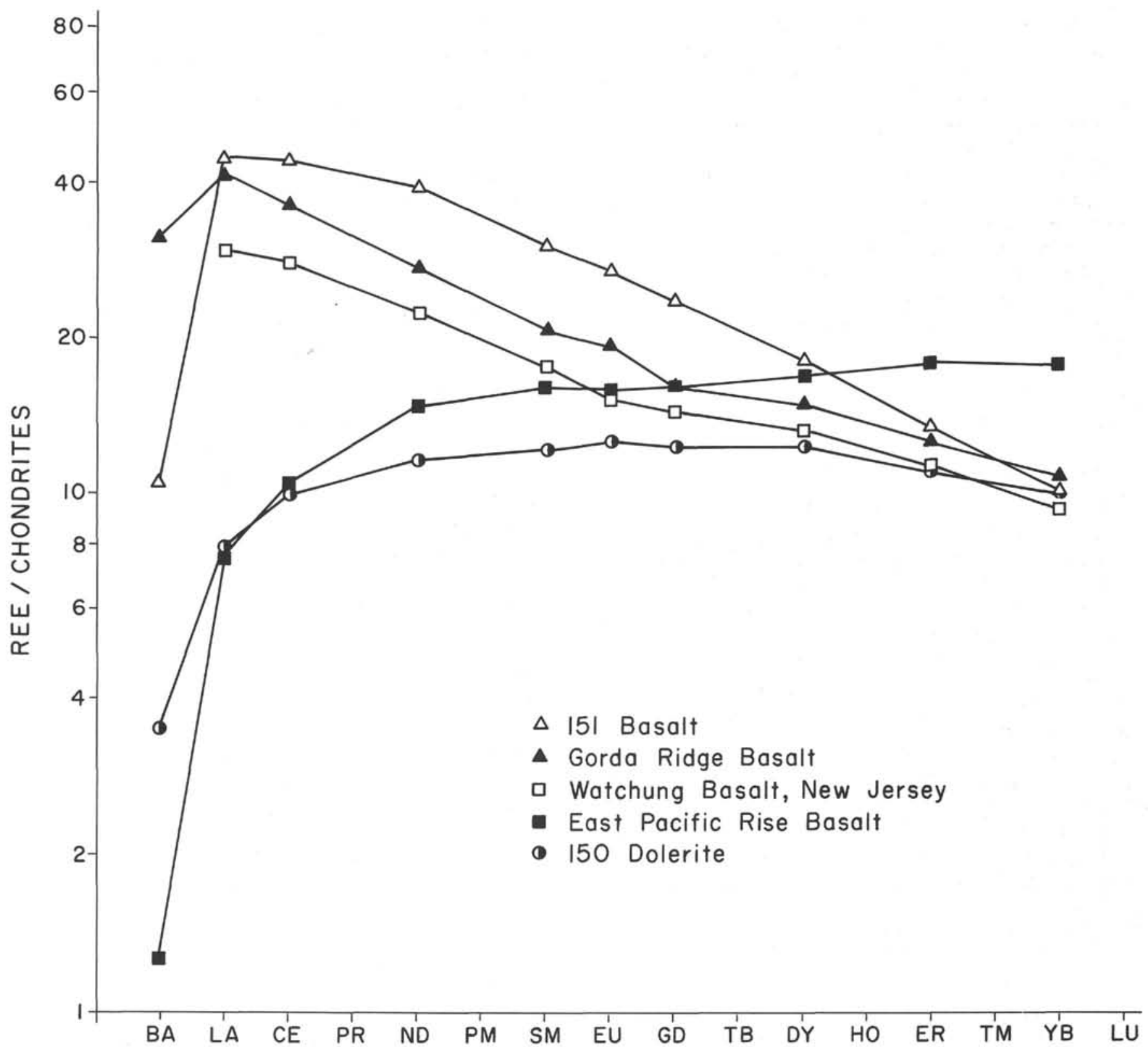

Figure 11. Rare earth concentrations in two Leg 15 basaltic rocks (plotted as in Figure 10) showing similarity of light rare earth depleted type (Site 150) and a mid-ocean ridge basalt (sample P6702-44, from Kay, et al. 1970); and the similarity between a light rare earth enriched type (Site 151) and Triassic basalt from New Jersey (sample GE 1662, from Kay, et al, 1970), and a less common mid-ocean ridge basalt (sample $7 F$, from Kay, et al, 1970). The rare earth pattern of CURDRY (see Figure 10) is almost chondritic, and is similar to midocean ridge basalt KD-11 (Kay, et al, 1970).

some samples this similarity includes the whole RE pattern (Sites 146, 150, 153).

2) Samples wither total RE content have higher total $\mathrm{Fe}$, lower $\mathrm{A} 1$, and small negative Eu anomalies.

Kay, Hubbard, and Gast (1970) have presented a model to explain these features in midocean ridge tholeiites. Briefly summarized, the model holds that the light-RE depletion is inherited from a previously depleted peridotite source region. A large percentage of melting (20-30\%) accompanying diapiric uprise of mantle to shallow depths leaves a mantle residue of olivine and orthopyroxene, which have low RE content: most of the
RE go into the melt. Low-pressure fractional crystallization of minerals low in the RE (olivine and plagioclase) enriches the rest magma in total RE. Plagioclase takes excess amounts of Eu, resulting in a small negative Eu anomaly in the rest magmas.

The mechanism for derivation of the upper Cretaceous Caribbean basalts may have been similar, yet may not have been localized about a single spreading axis. Rather the diapirs may have penetrated a large region behind the arc. Hawkins and Hishimori (1971) report similar recent basalts from between the Tonga and Lau ridges. The Puerto Rican amphibolite TD63-64 (Donnelly, et al., 1971) may be a 
metamorphic equivalent of the light-RE depleted Leg 15 basalts; a similar amphibolite has been dredged from the Mid-Atlantic Ridge (Kay, Hubbard, and Gast, 1970). Some island arc tholeiites have depleted light-RE, however, as well as the Ba enrichment found in this sample (Philpotts, Martin, and Schnetzler, 1971).

Whereas the chondritic RE distribution pattern in CURDRY may have been retained from a pocket of mantle not previously depleted in light-RE, the pattern in the Site 151 sample, which is similar to continental flood basalts (see Figure 11), shows a steady enrichment in light-RE and lack of an Eu anomaly. Thus, fractionation of the RE occurred in a region not containing plagioclase, presumably the mantle. Fractionation of heavy and light-RE by the calcic minerals clinopyroxene and garnet results in the general features of the distribution (Kay, 1970; Philpotts, Martin, and Schnetzler, 1971). Melting must not have progressed enough to destroy the $\mathrm{Ca}$-bearing minerals in the mantle source region of this basalt.

\section{Summary of Chemical Characteristics}

The easternmost Leg 15 samples are typical of midocean tholeiites. The Beata Ridge basalt (Site 151) has the higher potassium and thorium, and the light-RE enriched character of several continental tholeiites, but such character is also known from oceanic situations. The Site 152 basalt is more problematical; it is somewhat weathered, but has higher Th content than a typically oceanic basalt. In general, it is closer to the Site 151 basalt (and to the Jamaican dolerite) than to the more easterly samples. Although the chemical characteristics of these mafic igneous rocks could conceivably be explained by differentiation of an originally homogenous magma, the occurrence of the high-K, high-Th samples in the topographically higher areas (Beata Ridge, flank of Nicaraguan Rise, Jamaica) suggests more strongly the presence of continental crust in these places.

\section{CIRCUM-CARIBBEAN IGNEOUS ACTIVITY OF THE LATE CRETACEOUS}

Figure 12 shows a map locating the five Leg 15 basalt-dolerite sites; the Curacao, Aves Ridge, and Jamaican samples analyzed; occurrences of basaltic and related lavas in Costa Rica, Panama, Venezuela, and Puerto Rico (including, partly for the sake of argument, the potassic Lapa lavas of central Puerto Rico and the Siquesique ophiolites near Barquisimeto, Venezuela); and acid intrusives of comparable ages. Figure 13 is a histogram of radiometric age dates from the Greater Antilles and from northeastern South America, as well as the age ranges of the Leg 15 basalt and of the subalkalic volcanic debris (Donnelly, this volume) in the Leg 15 cores. The coincidence of late Cretaceous ages for all areas is noteworthy, although igneous activity (acid plutons) continued in the Greater Antilles into the Eocene.

The distribution of roughly coeval igneous events shown in Figure 12 and the possible identification as dolerite or basalt of Reflector $B^{\prime \prime}$, which occurs in the northern part of the Colombian Basin (Edgar, Ewing, and Hennion, 1971), suggest that the total area of igneous activity might encompass virtually all of the Caribbean west of the Aves Ridge, with the possible exception of the southern Colom- bian Basin where thick turbidites prevent the identification of Reflectors $A^{\prime \prime}$ and $B^{\prime \prime}$. In any case, the igneous event responsible for these occurrences would appear to be very widespread and to be manifested in areas of varying tectonic style. The great distance behind the island arcs of these central Caribbean basalts (as well as the very low potassium of three of them) would seem to make any connection between their generation and island arc tectonics (subduction and melting along the Benioff Zone) wholly improbable. Rather it appears that the igneous event was independent of local tectonic styles and represents a more regional thermal or thermal-tectonic event. The subalkalic late Cretaceous volcanic events discussed elsewhere in this volume (and represented in Leg 15 cores by the quartz-biotite-alkali feldspar association; Donnelly, this volume) might represent a more silicic differentiate of this event, which is confined to areas of continental crust. The recognition of a single eastern Caribbean igneous event of this size would make this a truly gigantic igneous province, and the inclusion of the Colombian Basin and southern Central American would make this event one of the most widespread Phanerozoic igneous events in the world. More important than the extent of the igneous activity, is the recognition that typical oceanic tholeiites can be erupted over a broad area nearly simultaneously instead of only along a line, and that island arc and deep-basin igneous activity, while producing compositionally different products, may be caused by the same thermal event.

\section{CHARACTER OF ANOMALOUS $7.2 \mathrm{KM} / \mathrm{SEC}$ CRUST IN THE CARIBBEAN}

The thick layer of about $7.2 \mathrm{~km} / \mathrm{sec}$ velocity that underlies the Venezuelan Basin and possibly the Colombian Basin (Officer, et al., 1959. Edgar, Ewing, and Hennion, 1971) is anomalous; outside of midocean ridge areas, few oceanic regions of the world show such a thick ( 3 to $8 \mathrm{~km}$ in the central Venezuelan Basin) layer of a velocity higher than typical oceanic crust but lower than typically oceanic mantle. Officer, et al. (1959) considered that this material owed its atypical velocity distribution to alteration, and surmised, "that this alteration had occurred principally through the introduction of material from depth in the mantle." Officer, et al, implied no particular age for this alteration. Donnelly (1964) considered that this velocity was too high for crustal material and must represent mantle. He postulated that this material was hydrated upper mantle and that it predated the island arc, which would make it Jurassic or older.

The discovery of apparently ubiquitous basalts and dolerites of late Cretaceous age in the central Caribbean now would seem to lend considerable credence to the view of Officer, et al. Either there could be sufficient basaltic magma brought up from the mantle to prevade and effectively lower the velocity of the upper mantle-lower crust, or an igneous event of such magnitude might be accompanied by pervasively rising volatiles, which would hydrate this mantle. In either case, the argument that the Venezuelan Basin $7.2 \mathrm{~km} / \mathrm{sec}$ layer antedated the island arcs of the eastern Caribbean has to be considered as having been seriously weakened. 


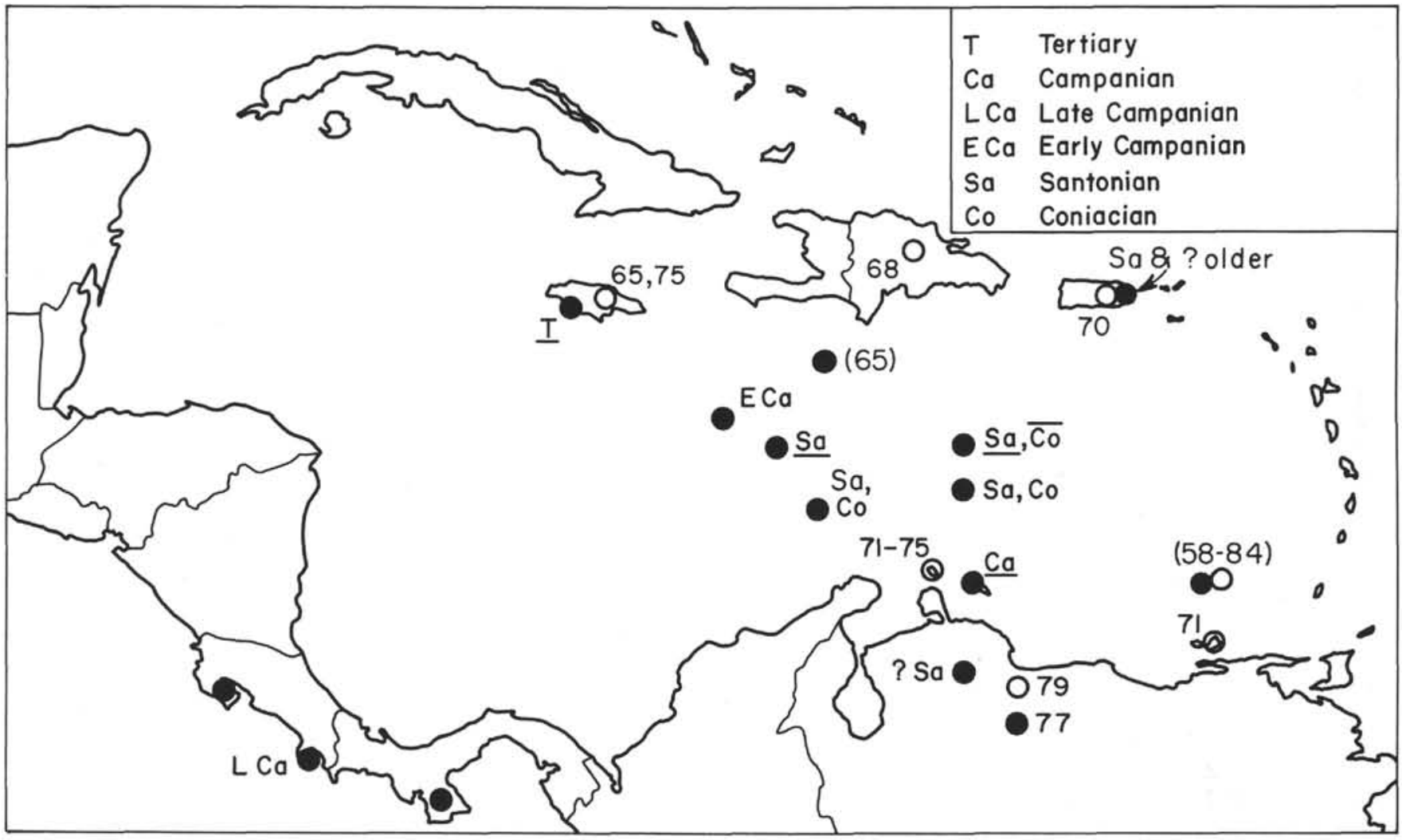

Figure 12. Map of the Caribbean area showing occurrences of basaltic rocks (filled circles) and acid plutonic rocks (open circles) with ages apparently similar to Leg 15 basalt/dolerite occurrences. Underlined symbols indicate dated material overlying basalt/dolerite, overlined symbol indicates intrusive relationship. Some radiometric ages shown (in millions of years). Parentheses indicate possible uncertainty of age of dredged samples. References for radiometric dates given in Figure 13.

\section{ACKNOWLEDGMENTS}

P. J. Fox, R. Wright, and J. Lewis provided samples of basic igneous rocks and unpublished results. R. Senechal assisted with mass spectrometry. The support of the National Science Foundation (Grant GA 16457) is acknowledged. M. Budd performed the chemical analyses, and Jan O'Brien and A. J. Donnelly assisted in many ways in the preparation of the manuscript.

\section{REFERENCES}

Banks, H., 1972. Iron-rich saponite; additional data on samples dredged from the MAR $22^{\circ} \mathrm{N}$. Smithsonian Contributions to Earth Sci. 9, 39.

Compston, W., McDougall, I. and Heier, K. S., 1968. Geochemical comparison of the Mesozoic basaltic rocks of Antarctica, South Africa, South America, and Tasmania. Geochim. et Cosmochim. Acta. 32, 129.

Dengo, G., 1962. Tectonic-igneous sequence in Costa. In Petrologic Studies: A Volume in Honor of A. F. Buddington. Geol. Soc. Am. 133.

Donnelly, T. W., 1964. Evolution of eastern Greater Antillean island arc. Bull. Am. Assoc. Petrol. Geol. 48, 680.

Donnelly, T. W., Rogers, J. J. W., Pushkar, P. and Armstronc, R. L., 1971. Chemical evolution of the igneous rocks of the eastern West Indies: an investigation of thorium, uranium, and potassium distributions and lead and strontium isotopic ratios. Geol. Soc. Am. Mem. 130, 181 .
Edgar, N. T., Ewing, J. I. and Hennion, J., 1971. Seismic refraction and reflection in Caribbean Sea. Bull. Am. Assoc. Petrol. Geol. 55, 833.

Engel, C. G. and Engel, A. E. J., 1963. Basalts dredged from the northeastern Pacific Ocean. Science. 140, 1321.

Engel, C. G. and Engel, C. G., 1964. Composition of basalts from the Mid-Atlantic Ridge. Science. 144, 1330.

Fox, P. J., Ruddiman, W. F., Ryan, W. B. F. and Heezen, B. C., 1970. The geology of the Caribbean crust, I: Beata Ridge. Tectonophysics, 10, 495.

Fox, P. J., Schreiber, E. and Heezen, B. C., 1971. The geology of the Caribbean crust: Tertiary sediments, granitic and basic rocks from the Avis Ridge. Tectonophysics. 12, 89 .

Gottfried, D., Greenland, L. P. and Campbell, E. Y., 1968. Variation of $\mathrm{Nb}-\mathrm{Ta}, \mathrm{Zr}-\mathrm{Hf}, \mathrm{Th}-\mathrm{U}$, and $\mathrm{K}-\mathrm{Cs}$ in two diabasegranophyre suites. Geochim. et Cosmochim. Acta. 32, 925.

Hawkins, J. and Nishimori, R., 1971. Ocean ridge type tholeiitic rocks from the Lau Basin: their petrology and significance. (abs) Geol. Soc. Amer. 1971 Annual Meetings. Abstracts with Programs. 3, 594.

Heier, K. S., Chappell, B. W., Arriens, P. A. and Morgan, J. W., 1966. The geochemistry of four Icelandic basalts. Norsk Geoloqisk Tids. 46, 427.

Heier, K. S. and Rogers, J. J. W., 1963. Radiometric determination of thorium, uranium and potassium in basalts and in two magmatic differentration senes. Geochim. et Cosmochim Acta. 27, 137. 


\section{Northern Venezuela, Aruba, Aves Ridge}

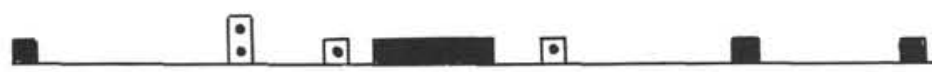

\section{Greater Antilles, Beata Ridge}

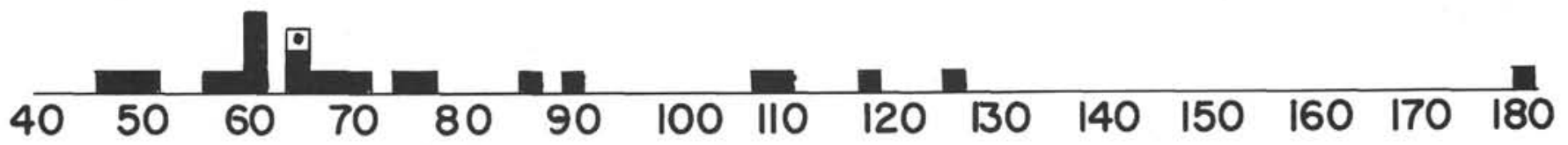

Figure 13. Histogram of radiometric $(K-A r)$ age dates from Greater Antilles and the Beata Ridge and from northern South America and the Aves Ridge. Open squares with dots indicate possible uncertainty of age of dredges samples. Black bar for Leg 15 represents age of basalt/dolerite occurrences; white bar represents occurrences of alkalic volcanic detritus in central Caribbean sites. Aves Ridge samples, shown as open boxes, are partially altered. (References for age dates: Meyerhoff and Khudoley, 1971; Fox, et al., in press; Martin B., et al., 1968; Priem, et al., 1966; Fox, et al., 1970).

Hennigsen, V. D. and Weyl, R., 1967. Oceanic crust in the Nicoya-Complex of Costa Rica.

Kay, R., 1970. The Rare Earth Geochemistry of Alkaline Basaltic Volcanics. Rh.D. thesis, Columbia Univ. 1970.

Kay, R., Hubbard, N. and Gast, P. W., 1970. Chemical characteristics and origin of oceanic ridge volcanic rocks. J. Geophys. Res. 751585.

Kuno, H., Yamasaki, K., Jida, C. and Hagashima, K., 1957. Differentiation of Hawaiian magmas. Jap. J. Geology and Geography. 28, 179.

MacDonald, G. A., 1949. Petrography of the Island of Hawaii. U.S. Geol. Survey Prof. Paper 214D. 51.

Melson, W. H., Thompson, G. and VanAndel, T. H., 1968. Volcanism and metamorphism in the Mid-Atlantic Ridge, $22^{\circ} \mathrm{N}$ Latitude. Geophys. Res. 73, 5925.

Morgan, J. W. and Lovering, J. F., 1965. Uranium and thorium abundances in the basalt cored in Mohole project (Guadalupe Site). J. Geophys. Res. 70, 4724.

Officer, C. B., Ewing, J. I., Hennion, J. F., Harkrider, D. G., and Millder, D. E., 1959. Geophysical investigations in the eastern Caribbean: summary of 1955 and 1956 cruises. Physics and Chemistry of the Earth, V. 3. In L. H. Ahrens, F. Press, K. Rankama, and S. K. Runcorn, (Eds.). Pergamon Press, 17.

Philpotts, J. A., Martin, J. M. and Schnetzler, C., 1971. Geochemical aspects of some Japanese lavas. Earth Planet. Sci. Letters. 12, 89.

Priem, H. N. A. et al., 1967. Beknopt versalg over de werkzaamheden in het jaar von September 1966 tot Stptember 1967. Z.W.O. Labaratorium boor isotopengeologie, Amsterdam.

Shapiro, L., 1967. Rapid analysis of rocks and minerals by a single solution method. U.S. Geological Survey Prof. Paper 575-B. B187.

Shapiro, L. and Brannock, W. W., 1962. Rapid analysis of silicate, carbonate, and phosphate rocks. U.S. Geological Survey Bulletin 1144-A.
Tatsumoto, M., 1966. Isotopic composition of lead in volcanic rocks from Hawaii, Iwo Jima, and Japan. J. Geophys. Res. 71, 1721.

Tatsumoto, M., Hedge, C. E., and Engel, A. E. J., 1965. Potassium, rubidium, strontium, thorium, and uranium and the ratio of strontium- 87 to strontium- 86 in oceanic tholeiitic basalt. Science. 150, 886 .

Watkins, N. D., Holmes, C. W. and Hagerty, S. E., 1967. Primary oxidation variation of uranium and thorium in a lava flow. Science. 155, 579.

\section{APPENDIX: PROCEDURE FOR CHEMICAL ANALYSIS}

For major element analysis, the procedure was as follows. The samples were air dried for several days at $120^{\circ} \mathrm{C}$ after having been finely ground. The so-called rapid procedures of Shapiro and Brannock (1962) and Shapiro (1967) were followed, with some modifications. Samples were digested in a lithium metaboratelithium tetraborate fusion and the bead dissolved in a weak sulfuric acid solution.

Silicon was determined by colorimetric methods by the molybdenum blue method. Aluminum was determined by a colorimetric method using the calcium alizarin red method. Total iron was determined by absorption flame photometry; ferrous iron was determined on an aliquot decomposed with a HF- $\mathrm{H}_{2} \mathrm{SO}_{4}$ mixture by titration against standard potassium dichromate, using sodium diphenylamine sulfonate as an indicator. Titanium was determined by colorimetric methods using Tiron as an indicator. Phosphorus was determined by a colorimetric method involving molybdenum blue with stannous chloride reduction. Manganese, sodium, potassium, magnesium, and calcium were determined by absorption flame photometry, using lanthanum in all samples. Bound water was determined by weighing evolved water in a sodium tungstate fusion. Carbon dioxide was determined from a volumetric measurement of evolved $\mathrm{CO}_{2}$ with a hydrochloric acid-mercuric chloride mixture. The colorimeter used is a Beckmann Model DU. The absorption flame photometer is a Perkin-Elmer Model 303 with digital readout.

Thorium and uranium were determined at Rice University by gamma-ray spectrometry of 400-gram, crushed samples.

The rare earths and barium were determined at Lamont-Doherty Geological Observatory, using mass spectrometric procedures. 



\section{PLATE 1}

Thin Sections of Dolerites from Site 146

(Bar in Figure 8 gives scale for Figures 1-5, 7, and 8, and is $0.5 \mathrm{~mm}$. long)

Figures 1-5 Photos showing textural variations through lower sill at Site 146. Principal minerals are plagioclase (white laths, low relief), augite (gray, more equant grains, higher relief), ?saponite (medium to dark gray, interstitial), and oxides (black, with crystal faces). (1) 146-42R-1(117-120); (2) 146-42R-3(41-44); (3) 146-43R-2(121-125); (4) 146-43R-4(27-30); $146-\mathrm{R}(\mathrm{CC})$.

Figure $6 \quad$ Enlarged view of dolerite from upper sill, showing plagioclase, augite, and ?saponite. 146-41R-2(50-54). Bar is 100 microns long.

Figure 7 Same slide as Figure 6, but at smaller scale of other figures, and showing oxide grains.

Figure $8 \quad$ Chilled lower border of upper sill, showing large augite crystal in finer-grained groundmass. 146-41 R-2(119-122). 


\section{PLATE 1}

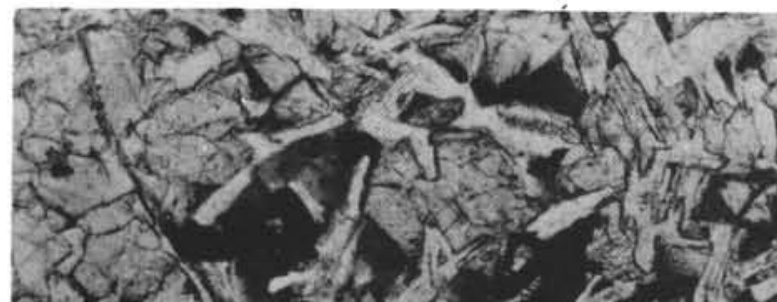

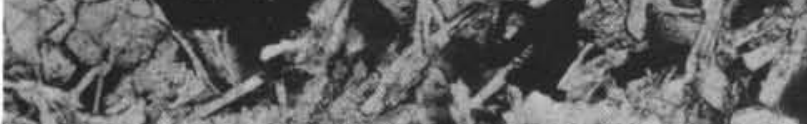
2.

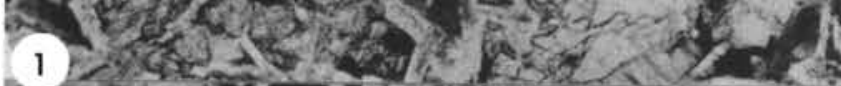

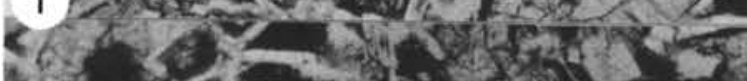

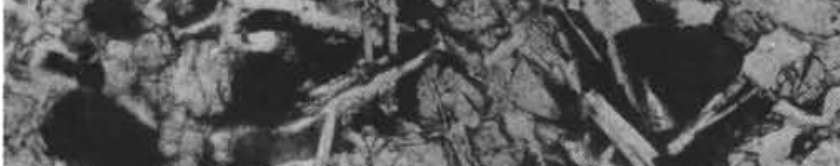

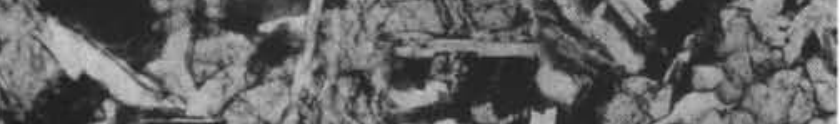

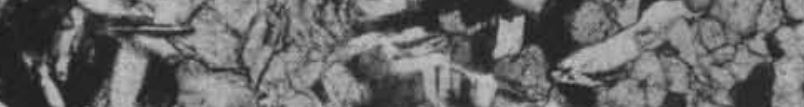

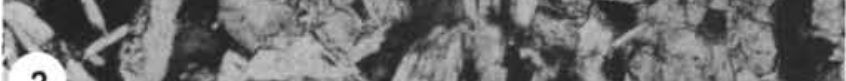

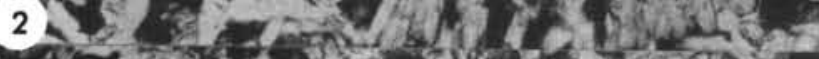

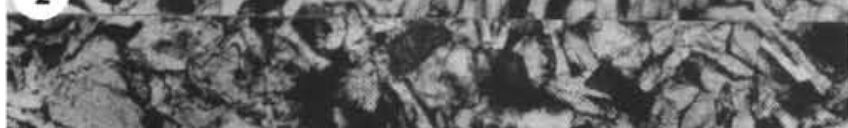

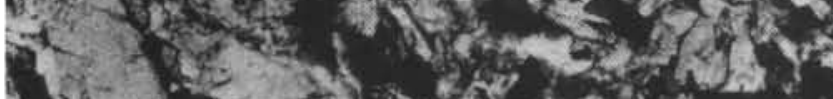

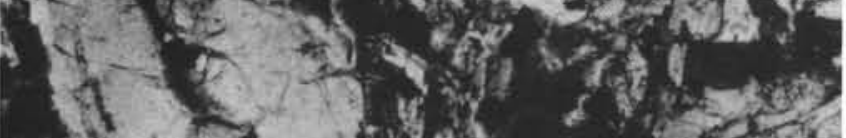
E.t.

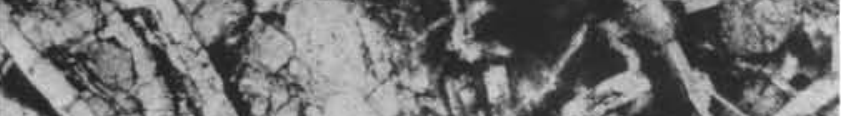

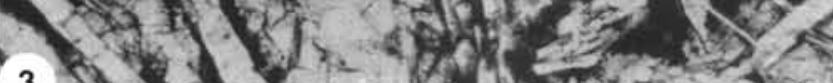

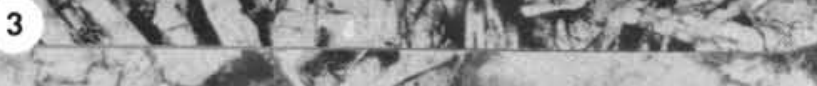

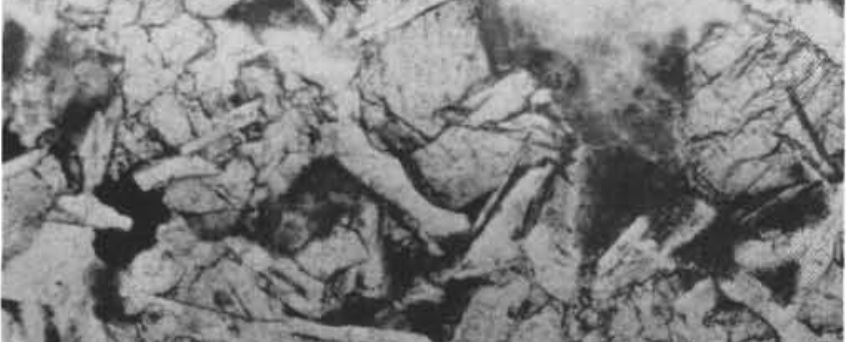

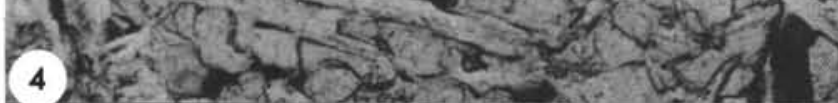
(4)

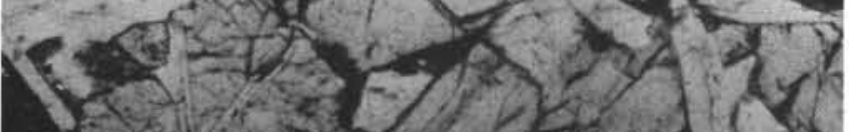

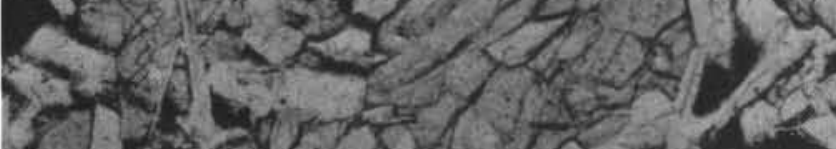

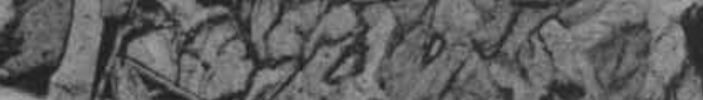
ate
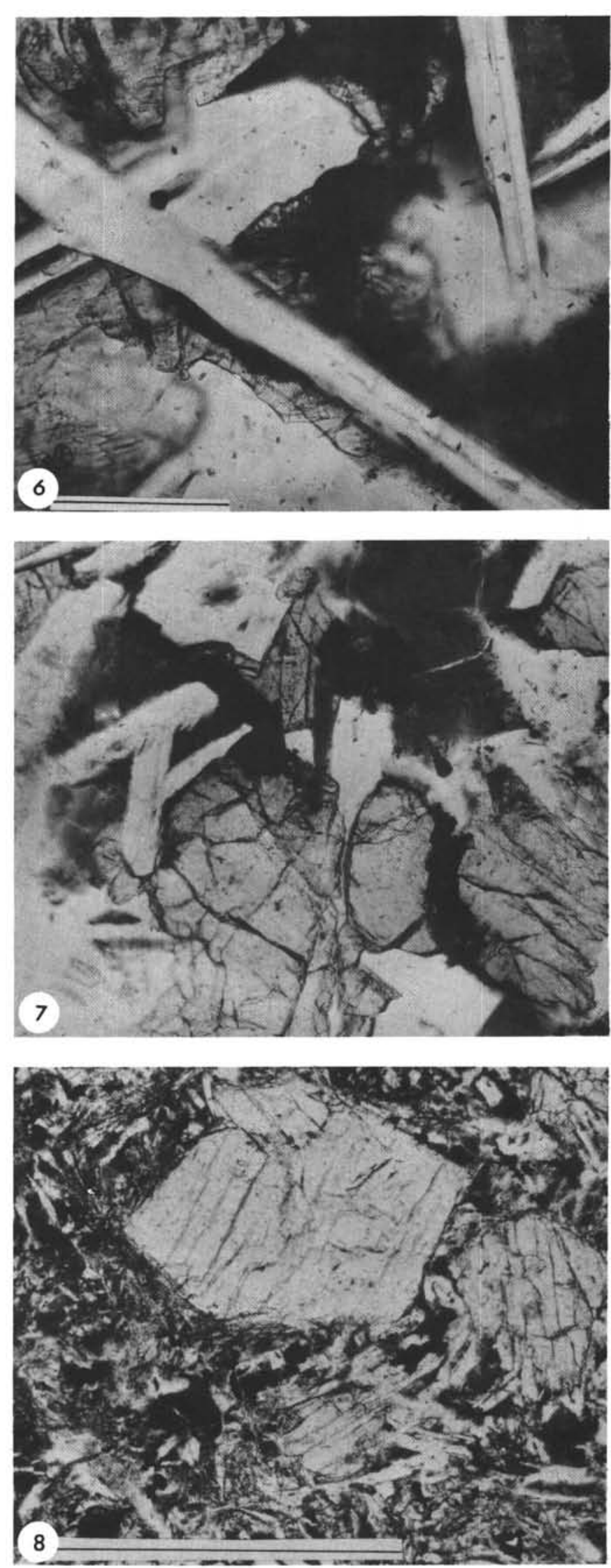


\section{PLATE 2}

Thin Sections of Dolerites (Site 150) and Basalt (Site 151)

(Bar scale applies to Figures 1, 2, 3-6)

Figure 1 Fine-grained dolerite, showing augite, plagioclase, and ?saponite. 150-11-2(63-67).

Figure 2 Coarser dolerite. 150-12-1(130-135).

Figure 3 Early amygdular filling (very fine grained, pale mica) fractured and recemented by distinctly greener mica. $151-14-1(116-122)$. Bar is $0.5 \mathrm{~mm}$ long.

Figures 4-6 Porphyritic basalt, showing ?glomeroporphyritic aggregates of feldspar, with marginal mica. (4) $151-13$ (CC). (5) $151-14-1(116-122)$. (6) $151-15-1$ (146-150). 
PLATE 2
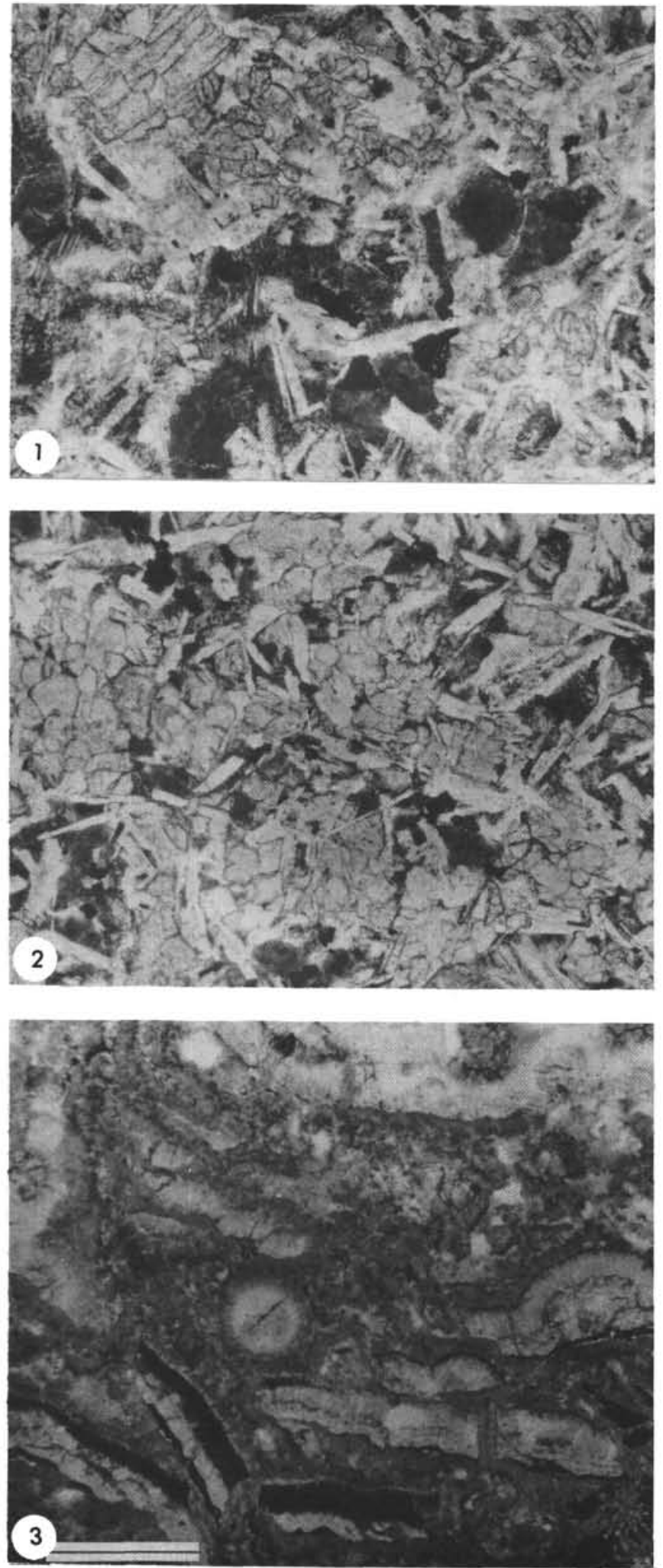
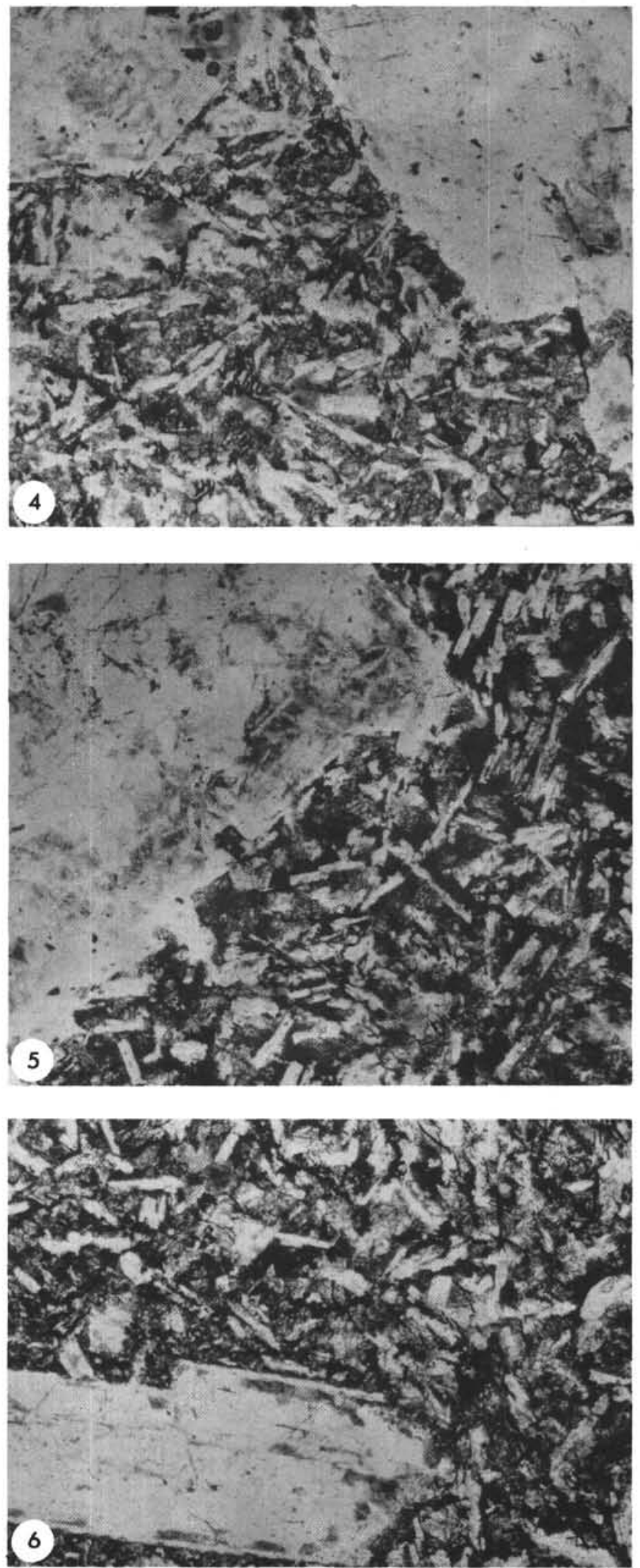

$10 \quad 0.5 \mathrm{~mm}$ 


\section{PLATE 3}

Thin Sections of Basalts (Sites 152, 153, Curacao)

(Bar scale applies to Figures 2-6)

Figure 1

Figure 2

Figure 3

Figure 4

Figure 5

Figure 6
Fine-grained, partially vitric basalt, showing plagioclase laths, plumose pyroxene, glass, and oxides. 153-19-1(116-120). Bar is 100 microns long.

Same slide as Figure 1, at smaller scale of other phtos.

Coarser basalt. 153-20-2(80-84).

Amygdular basalt. Amygdule filling is very finegrained mica. 152-23-1(107-121).

Amygdular basalt with nascent glomeroporphyritic clot of ophitically intergrown augite and plagioclase. 152-24-2(73-77).

Low-grade meta-basalt from Curacao Drydock (CURDRY). 


\section{PLATE 3}
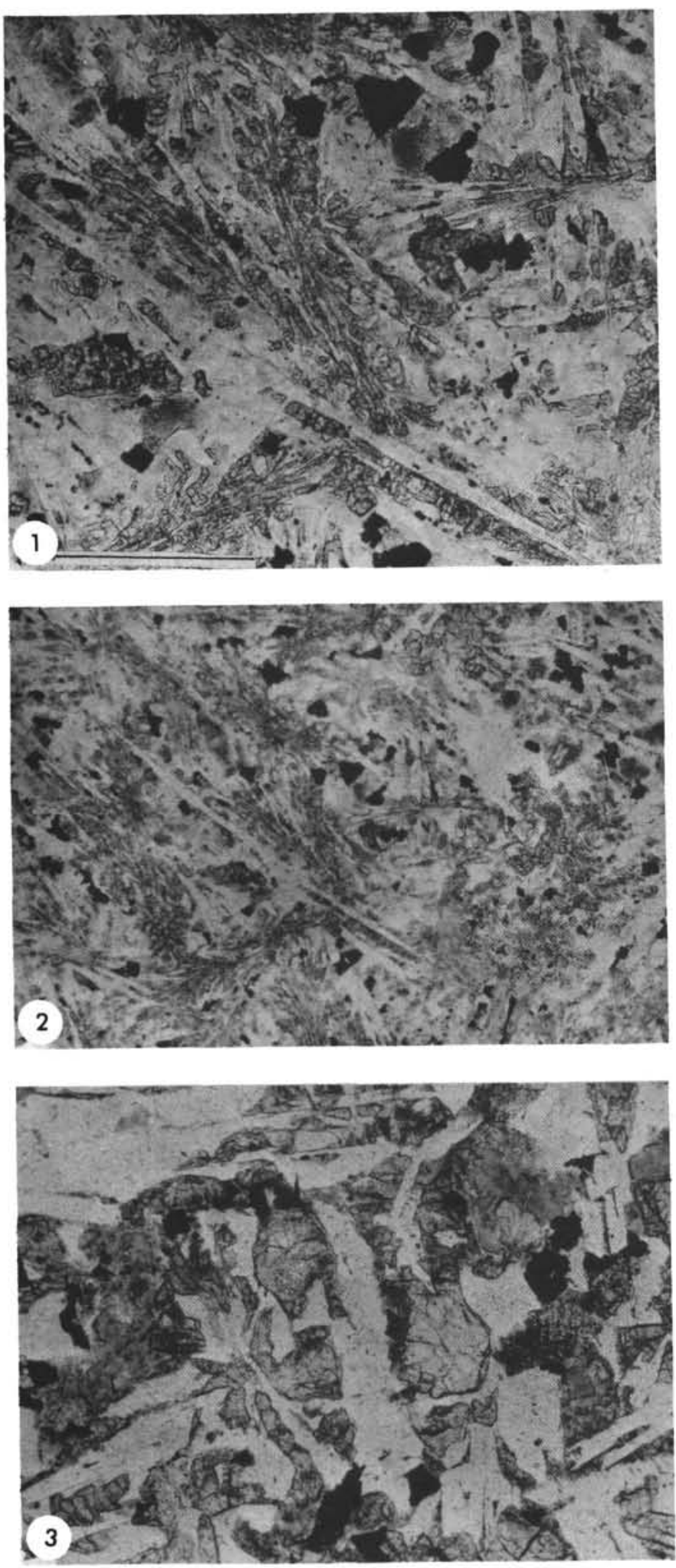

$0.5 \mathrm{~mm}$
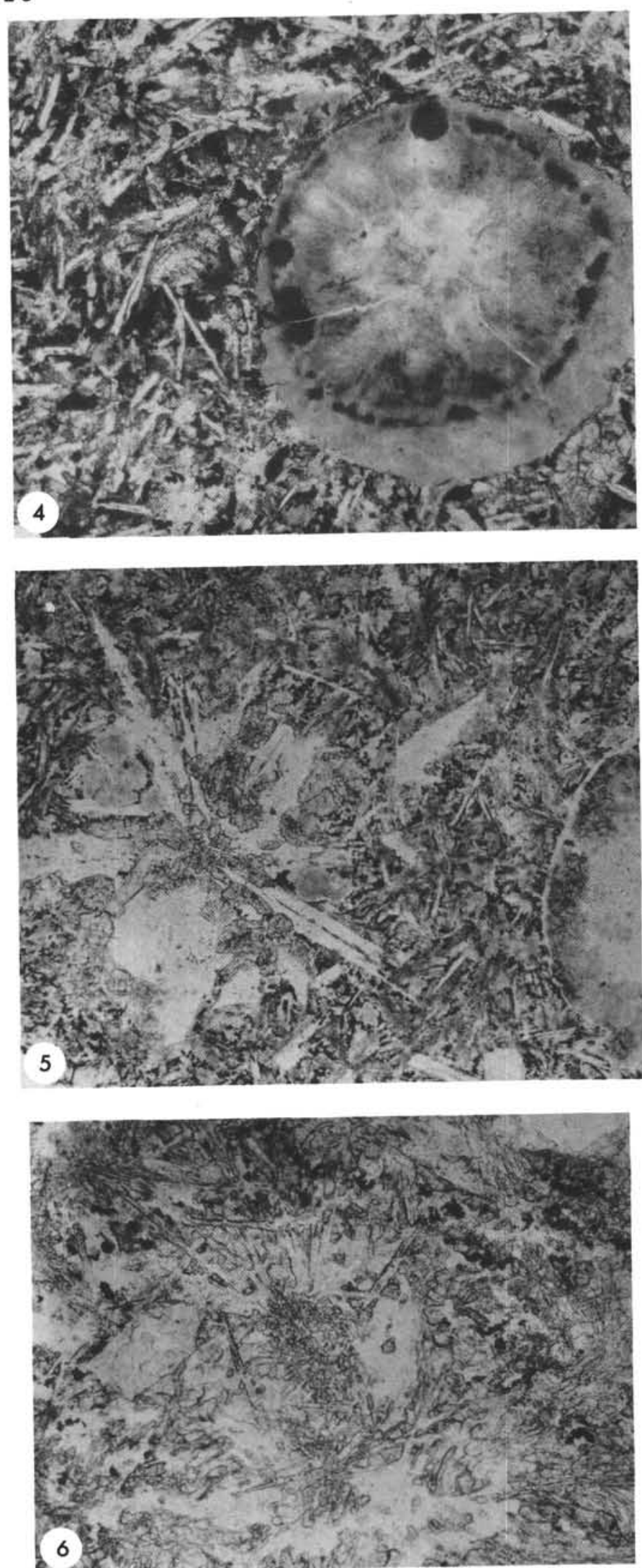